\title{
Bundled parking and vehicle ownership: Evidence from the American Housing Survey
}

\author{
Michael Manville \\ University of California, Los Angeles \\ mkm253@cornell.edu
}

\begin{abstract}
This article estimates the effect of bundled residential parking-parking whose price is included in the rent or purchase price of housing - on household vehicle ownership. Using data from the American Housing Survey, I show that the odds of households with bundled parking being vehicle-free are 50-75 percent lower than the odds of households without bundled parking, while households in dense center cities near transit are twice as likely to be without vehicles if they lack bundled parking. I also find substantial, though less stable, evidence that bundled parking encourages driving among commuters who have vehicles. These results are robust to a wide variety of demographic and land-use controls and to controls for residential self-selection. Examining self-selection shows that housing without bundled parking is sufficiently scarce and geographically concentrated that people who search for it may not find it. Four metropolitan areas, which hold 11 percent of U.S. housing units, hold more than 40 percent of its housing without bundled parking. Overall, the results suggest that when cities require parking with residential development, they increase vehicle ownership and use.
\end{abstract}

Keywords: Parking, built environment, vehicle ownership, land use, travel

\section{Article history:}

Received: January 19, 2014

Received in revised form:

September 12, 2015

Accepted: September 29, 2015

Available online: September 1,

2016

\section{$1 \quad$ Introduction}

Most Americans, when they buy or rent housing, also buy or rent at least one off-street parking space. They do so because the seller "bundles" the space with the housing-includes it in the housing's price. This rather ordinary arrangement could strongly influence vehicle ownership and use. Because most cars are parked most of the time, and spend more time parked at home than anywhere else, bundling moves a large cost of vehicle ownership (the cost of storage) into the price of housing. Parking becomes an element of housing consumption rather than travel behavior, and an expense that should fall only on vehicle owners instead falls on all housing consumers, regardless of whether they own vehicles. By separating the cost of storing vehicles from the cost of owning them, bundling could make owning and operating vehicles seem less expensive than it actually is. Marginal vehicle owners - those wavering

Copyright 2016 Michael Manville

http://dx.doi.org/10.5198/jtlu.2016.730

ISSN: 1938-7849 | Licensed under the Creative Commons Attribution - Noncommercial License 3.0

The Journal of Transport and Land Use is the official journal of the World Society for Transport and Land Use (WSTLUR) and is published and sponsored by the University of Minnesota Center for Transportation Studies. This paper is also published with sponsorship from WSTLUR and the Institutes of Transportation Studies at the University of California, Davis, and the University of California, Berkeley. 
about buying or keeping vehicles - are thus shielded from some of vehicle ownership's costs, because they pay for parking in their housing price. Put another way, bundling reduces the opportunity cost of vehicle ownership; people who don't own cars don't save money on parking.

It follows that people whose housing includes bundled parking might be more likely to own and use vehicles. One needn't own a vehicle to use one, of course, but households with vehicles drive much more than households without them. In the 2009 National Household Travel Survey, respondents from households without vehicles drove an average of 3800 miles per year, while households with vehicles averaged 12,300 miles.

This article uses the American Housing Survey (AHS) to estimate the relationship between bundled parking and vehicle ownership. To my knowledge, it is the first study to estimate this relationship using nationally representative data. I address self-selection using both instrumental variables and natural experiments that occur in subsamples of the AHS. My results suggest that bundled parking is strongly associated with vehicle ownership, and that this association is largely causal. People who might otherwise not own vehicles choose to do so when the cost of parking is hidden in the cost of their housing.

These findings have implications for both transportation and land-use policy. Bundling often results from minimum parking requirements in zoning codes; bundling is more common where parking requirements are higher (Manville, Beata, and Shoup 2013; Manville 2013). Parking requirements encourage bundling when they force developers to provide parking whose cost exceeds its market value, leaving developers little choice but to include spaces in the price of housing (Shoup 2005). My results therefore lend support to the growing case against minimum parking requirements. If parking requirements lead to bundling, and bundling increases vehicle ownership and use, then municipal efforts to fight congestion through parking requirements will be ineffective and perhaps even counterproductive. The results also suggest that efforts to remove parking requirements needn't exacerbate local congestion. Neighbors often support parking requirements because they believe buildings without off-street parking will still attract many residents with vehicles, who will compete for scarce street parking. An opponent of parking reform in Boston, for example, told the Boston Globe, "The city is asking us to believe that the people moving into the neighborhood [won't] own cars, and we're just not seeing that" (Ross 2013). But if units without bundled parking are more likely to house people without vehicles, concerns about curb spillover may be overstated, and the local costs of parking reform may be lower than opponents believe.

The article's next section reviews existing research about transportation and the built environment and the role parking might play in that relationship. Section III describes the AHS, Section IV presents the analysis, and Section $\mathrm{V}$ provides the conclusions.

\section{Parking, vehicle ownership and the built environment}

This article contributes to the relatively small research literature on vehicle ownership, the larger literature on travel and the built environment, and the growing literature on how parking influences travel choices. Studies of travel and the built environment generally characterize various land uses as cumulatively increasing or decreasing the price of particular travel modes, usually by changing the time or stress involved in completing a trip (Boarnet 2011). For example, a dense area with many buildings and narrow streets can make driving slow and unpleasant (and thus more expensive), while making rail transit more efficient and walking safer and more interesting (and thus less expensive). Chatman (2010) suggests that the former is more important than the latter-built environments that increase driving's price have larger travel impacts than those that reduce the price of other modes.

Studies examining travel and the built environment number in the hundreds, and most find that the built environment influences vehicle use. Most of these studies do not specifically examine the decision to own a vehicle but instead measure total travel by different modes. Those studies that do focus on 
vehicle ownership are somewhat less conclusive, although all suggest that the built environment influences vehicle ownership (i.e., Zegras 2010; Chu 2002; Cao, Mokhtarian, and Handy 2007).

Few studies of travel and the built environment examine residential parking, or even parking more broadly. Boarnet and Crane's (2001) influential book on travel and the built environment mentions parking only in a footnote. Residential parking goes unmentioned in Handy's (2005) review of the transportation and land-use literature and in Bento et al.'s (2005) study of travel behavior and urban spatial structure. Salon's (2009) examination of travel and the built environment in New York does not analyze parking but calls it a "missing link" that might bias the study's results through its absence. Cervero and Ewing's (2010) meta-analysis of travel and land use examined 200 published and unpublished studies, almost none of which included residential parking. Boarnet's (2011) review and synthesis of the travel and built-environment literature does not mention parking at all.

Scholars neglect parking largely because parking data are scarce. The US government extensively tracks roads and vehicles but not parking spaces. Most local governments also do not collect parking data, even though almost all require off-street parking with development. Some researchers have tried to count parking spaces using maps or satellite photos (Davis et al. 2010; McCahill and Garrick 2010; Guo 2013a, 2013b; Weinberger 2012), but in the dense areas where parking is most expensive-and thus most likely to shape travel decisions - many spaces are hidden in structures or underground.

While parking's absence from many studies is understandable, it is not trivial. Parking is a large part of the built environment, and easily the largest part devoted explicitly (and often exclusively) to automobiles (Manville and Shoup 2005; Chester, Horvath, and Madanat 2010). Further, the supply of off-street parking is also the most dynamic aspect of vehicular infrastructure. Because cities everywhere require new parking with new development, the parking supply increases with density, far more than the supply of road and freeway space. ${ }^{1}$ Not accounting for parking's presence could therefore lead to biased estimates of other built environment attributes, like housing and population density. For example, suppose a developer constructs two identical 50-unit apartment buildings, one in the densest part of New York City and one in the densest part of Los Angeles. Each building holds 100 people. Los Angeles would require 63 parking spaces in this building, all reserved for residents, while New York would require none (Manville et al. 2013). Now assume (not unrealistically) that the Los Angeles building's parking spaces are hidden underground and bundled with rent. The result would be two parcels with equal population and housing densities, which look identical from the street and the air, but which have very different prices for vehicle ownership and driving.

When researchers are able to assemble parking data, they generally find a strong relationship between residential parking availability, vehicle ownership, and vehicle use. Weinberger, Seaman, and Johnson (2009) studied two Brooklyn neighborhoods and found that on-site parking increased the likelihood of residents driving to work. Both the Weinberger (2012) and Guo (2013) studies of New York City yielded similar results. Chatman (2013) found that in northern New Jersey suburbs, on- and offstreet residential parking availability was the largest predictor of auto ownership and use, exerting more influence than density, transit availability, and other built-environment attributes. All these studies, however, are confined to a single city or metropolitan area, suggesting again the difficulty of assembling parking data. All are also in Greater New York, and three are in New York City, which is a transportation outlier in the United States.

\section{Data}

The AHS is a panel survey of American housing units carried out every two years by the Census Bureau. The survey contains both a national sample weighted to represent all housing units in the country, and an embedded metropolitan sample weighted to represent a select number of metropolitan areas and

${ }^{1}$ The supply of parking can also rise when development falls, as landowners demolish buildings and convert them to parking lots (e.g., Jakle and Scully 2004). 
their primary central cities. The metropolitan sample varies with each AHS, with between six and 12 different metropolitan statistical areas (MSAs) examined in each round. This article analyzes householdlevel data from the 2003 AHS (as I discuss later, I use some spatially aggregated metropolitan data from other years to build instrumental variables). I use the 2003 survey for two reasons. First, it precedes the economic downturn that began in 2008 and likely influenced vehicle ownership levels. Second and more important, the 2003 survey was the last to include representative subsamples of America's largest MSAs: New York, Chicago, and Los Angeles (2009's survey didn't include LA). ${ }^{2}$ The 2003 survey also includes samples of northern New Jersey (Newark), Detroit, and Philadelphia.

Since 1983, the AHS has asked two questions about residential parking. The first asks whether a housing unit includes a garage or carport in its rent or purchase price. The second, which requires answering only when the answer to the first question is no, asks whether some other form of off-street parking is included in the rent or purchase price. I combine these responses into a single dichotomous variable coded 1 if the housing unit includes at least one parking space in the rent or purchase price. In all my regressions this is the independent variable of interest.

The AHS does not, unfortunately, specify how many parking spaces are included, only that there is at least one. It also does not specify whether the parking is on- or off-site. Further, a "zero" response indicates only that a housing unit lacks bundled parking; the survey does not differentiate between housing where off-street parking is available for a separate price, or where no off-street parking is offered at all. Thus "housing without bundled parking" represents both housing where off-street parking is sold separately and housing without off-street parking. The "treatment" I examine is not the presence of offstreet parking but whether that parking is included in the housing's price.

The AHS shows that bundled parking is common and has been for some time. Figure 2, drawn from the 1985-2009 AHS national samples, shows that over 90 percent of US housing units include bundled parking, and that housing without bundled parking is more common in center cities and the Northeast.

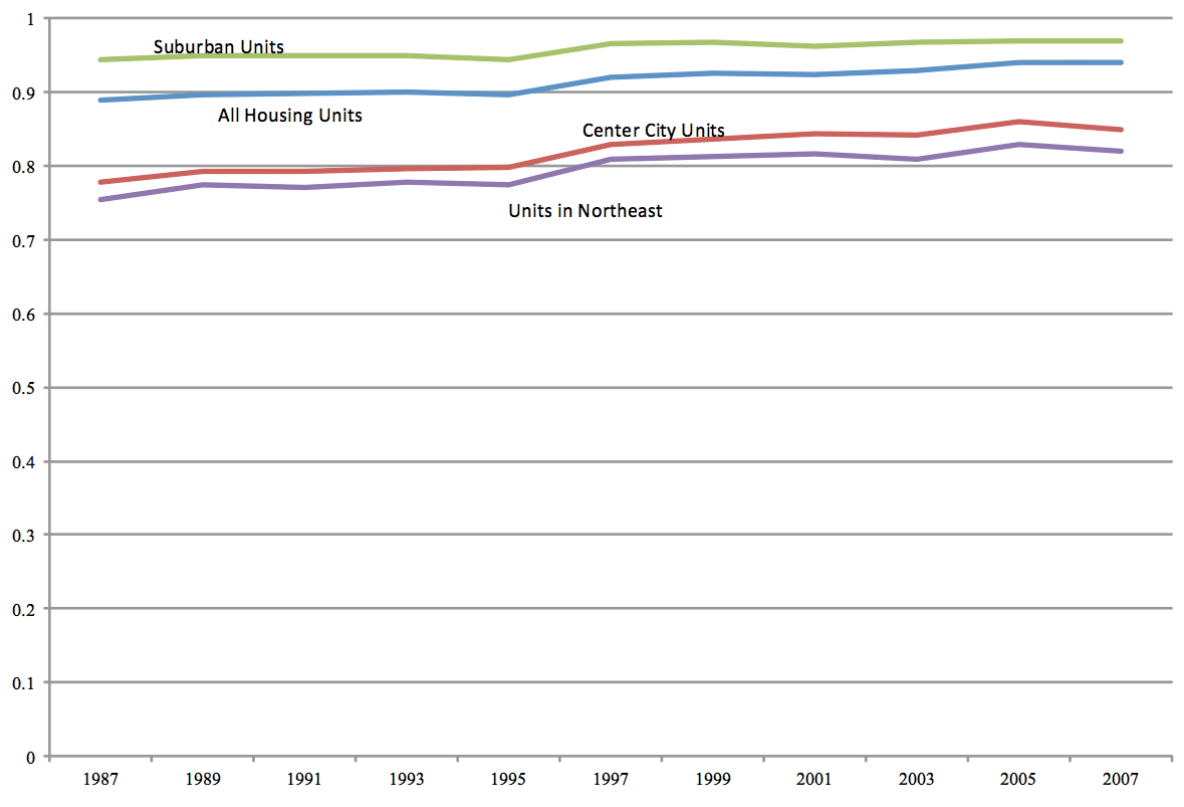

Figure 1: Share of occupied housing units with bundled parking, 1985-2009

Source: AHS national samples

${ }^{2}$ Comparing data from the 2000 Census and the 2006-11 American Community Survey suggests that the nationwide incidence of zero-vehicle households did not change much during that time: it was 10 percent in 2000 and 9 percent in 2006-11. There was, however, some variation within MSAs. Los Angeles' share of households with zero vehicles stayed constant at roughly 10 percent, but New York's rose from 30 percent to 40 percent. 
The AHS also asks about vehicle ownership, and I build a dichotomous variable coded 1 when a household has no vehicles, which I use as the dependent variable in most of my regressions. I also create variables that measure the number of vehicles per person in the household and the number of commuters who drive to work, and I use these as dependent variables in additional regressions.

These data alone suggest parking's potential importance in influencing travel behavior. Figure 2 combines data from the 2003-07 AHS metropolitan surveys and the Texas Transportation Institute (2011) to illustrate some simple relationships between bundled parking, density, vehicle ownership, and driving. The first panel plots the strong but not overwhelming negative relationship between population density and vehicle miles travelled $\left(\mathrm{R}^{2}=0.3\right)$. Panel 2 shows the considerably stronger negative relationship between population density and vehicle ownership $\left(\mathrm{R}^{2}=0.7\right)$. Note that in both panels New York and Los Angeles stand out: in Panel 1, New York is the far lowest value on the regression line, while Los Angeles is an outlier; in Panel 2, Los Angeles has fewer zero-vehicle households than its density would predict, and New York has more.

Panel 3, which plots the relationship between population density and the share of housing units with bundled parking, suggests an explanation for these anomalies. Most American MSAs have low population densities and high shares of bundled parking. New York, in contrast, is the only American MSA with high population density and a low share of bundled parking, while Los Angeles is the only American MSA with high population density and a high share of bundled parking. Bundled parking appears to explain more of the variance in driving than does density (Panel 4: $\mathrm{R}^{2}=0.50$ ), and more important, plotting bundled parking instead of density pulls Los Angeles back onto the regression line, suggesting that bundled parking could be an important intervening variable between density and vehicle travel. Lastly, Panel 5 shows the extremely strong relationship $\left(\mathrm{R}^{2}=0.91\right)$ between the share of bundled parking and vehicle ownership, with both New York and Los Angeles pulled back onto the regression line. 

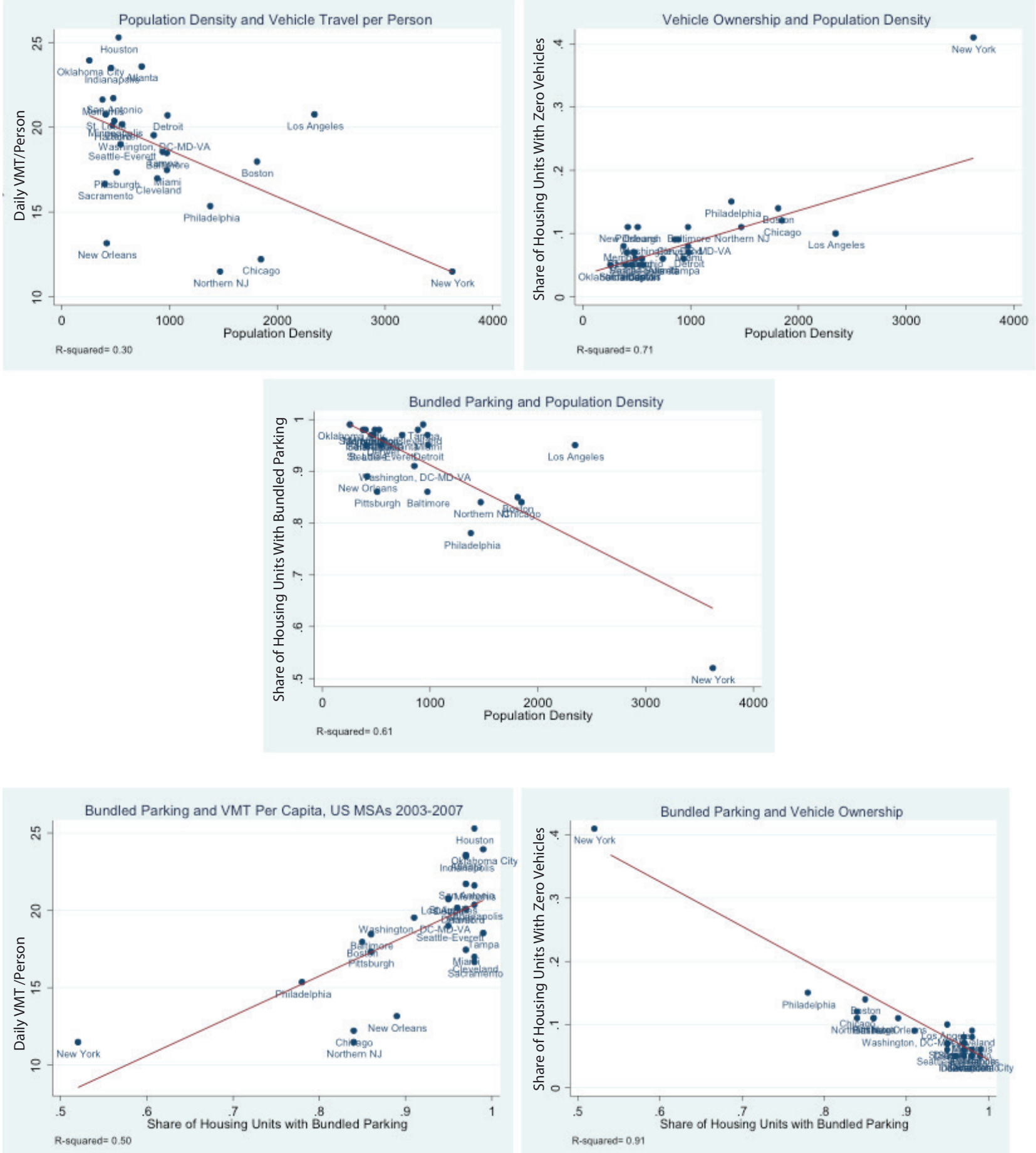

Figure 2: Bundled parking, population density, and vehicle ownership and use, US MSAs, 2003-07

Source: AHS and Texas Transportation Institute 
These relationships are of course bivariate and thus only suggestive; in my regressions, I control for an array of household characteristics predicting vehicle ownership. The most important of these is income. Because my dependent variable measures the probability of not owning a vehicle, in most regressions I use a dichotomous variable indicating poverty status rather than a linear variable measuring household income. I do so because owning no vehicle is likely a function of very low income. The total number of vehicles owned, in contrast, is likely to be a more linear function of income levels.

The remaining controls include the number of people in the household, the household's share of African-Americans (Giuiliano 2003), share of children under 18, share of foreign born (Chatman 2014), share age 65 or older, and share with a college degree or higher. Almost every regression also includes dummy variables indicating central city location, transit proximity, and if the unit is in a structure built before 1920. This latter variable proxies for the overall availability of residential off-street parking. Developers began providing parking in the 1920s, and cities began instituting minimum parking requirements in the 1930s (Shoup 2005). A pre-1920 building is also a crude proxy for a pre-automobile built environment (narrower streets, more intersections, etc.).

In later equations, I include variables that better capture different land-use and built-environment attributes. These variables control for the type of housing nearby, proximity to shops and offices, and so on. I do not use these variables in every specification because some have considerable nonresponse, making the sample size smaller.

Table 1 shows summary statistics for these measures. Like Figure 1, these statistics demonstrate the sheer prevalence of both bundled parking and vehicle ownership: over 90 percent of housing units include at least one parking space, and over 90 percent also have at least one vehicle. In contrast, only 55 percent of units are near a transit stop. The simple correlation between bundled parking and being vehicle-free is -0.29 , which is twice the correlation between transit availability and being vehicle-free (0.14). 
Table 1: Summary statistics for American Housing Survey household-level national data, 2003

\begin{tabular}{|c|c|c|c|c|}
\hline & Freq. & Percent of Total & & Total (N) \\
\hline \multicolumn{5}{|l|}{ Housing Unit and Demographic Attributes } \\
\hline Housing Units With No Vehicles & 4,135 & 8.6 & & 48,197 \\
\hline Units with Bundled Parking & 44,786 & 92.9 & & 48,197 \\
\hline Units In Poverty & 6,316 & 13.1 & & 48,197 \\
\hline \multirow[t]{2}{*}{ Units in Central Cities } & 14,194 & 29.5 & & 48,197 \\
\hline & Mean & $S D$ & $\operatorname{Max}$ & $N$ \\
\hline Proportion of $\mathrm{HH}$ with BA or Higher & 0.21 & 0.34 & 1 & 48,197 \\
\hline Proportion of HH Males & 0.47 & 0.31 & 0 & 48,197 \\
\hline Proportion of HH Children & 0.17 & 0.25 & 1 & 48,197 \\
\hline Number of Children in $\mathrm{HH}$ & 0.68 & 1.08 & 12 & 48,197 \\
\hline Proportion of HH Age 65 or Older & 0.42 & 0.33 & 0 & 48,197 \\
\hline \multicolumn{5}{|l|}{ Proportion of HH Foreign Born } \\
\hline Proportion of Household Black & 0.12 & 0.32 & 0 & 48,197 \\
\hline Total Household Vehicles & 1.82 & 1.11 & 10 & 48,197 \\
\hline Vehicles Per Person & 0.83 & 0.55 & 8 & 48,197 \\
\hline Persons in $\mathrm{HH}$ & 2.55 & 1.45 & 16 & 48,197 \\
\hline Household Income & $\$ 62,564$ & $\$ 147,483$ & $-\$ 10,000 \$ 9,999,996$ & 48,197 \\
\hline Year Structure Built & 1963 & 25 & 2003 & 48,197 \\
\hline Fraction of HH Commuters who Drive & 0.87 & 0.29 & 1 & 33,572 \\
\hline Commuters in $\mathrm{HH}$ & 1.60 & 0.71 & 8 & 33,572 \\
\hline Built Environment Attributes & Freq. & Percent of Total & & Total (N) \\
\hline Public Transportation Nearby & 26,362 & 54.7 & & 48,197 \\
\hline Unit Within 15 Minutes of Shops/Retail & 30,341 & 76.2 & & 39,830 \\
\hline \multicolumn{5}{|l|}{ Housing Unit Within 1/2 Block of: } \\
\hline High-Rise Apartment Buildings (7+ Stories) & 1,355 & 10.2 & & 13,330 \\
\hline Rowhouses or Townhouses & 6,250 & 13.4 & & 46,665 \\
\hline Apartments 4-6 Stories & 2,704 & 20.3 & & 13,304 \\
\hline Apartments Less then Four Stories & 10,777 & 22.6 & & 48,196 \\
\hline Single Family Homes & 38,014 & 81.0 & & 47,758 \\
\hline Businesses or Institutions & 11,839 & 24.6 & & 48,197 \\
\hline Abandoned Buildings & 2,225 & 5.0 & & 44,160 \\
\hline Industrial Uses & 1,637 & 3.4 & & 48,197 \\
\hline Parking Lots & 10,881 & 22.8 & & 46,902 \\
\hline
\end{tabular}

Source: American Housing Survey, 2003. Summary statistics are weighted to represent all housing units in United States.

\section{$4 \quad$ Analysis}

Table 2 shows seven logit regressions examining the odds that a household will be vehicle-free. The first regression analyzes the entire AHS national sample, while the remaining six analyze the representative subsamples of New York, Los Angeles, Chicago, northern New Jersey, Philadelphia, and Detroit. The national sample uses MSA fixed effects and is probability-weighted to represent the US 
housing stock (Watson 2007).

All the regressions show that households with bundled parking are much less likely to be vehiclefree. Each regression includes, in its bottom rows, two interpretations. The first is the percent change in the odds a household will be vehicle-free if it changes from unbundled to bundled parking. In most specifications, the odds a household with bundled parking will be vehicle-free are 70 to 80 percent less than the odds a comparable household without bundled parking will be vehicle-free. In Philadelphia and Detroit, the odds are 63 and 54 percent lower, respectively.

The second interpretation is a "probability shift" that uses the regression results to predict the probability that two stylized households will be vehicle-free. The first household is a non-poor, central city household near public transit that is "average" in every other way (i.e., all other variables are held at their means). This household does not have bundled parking. The second household is identical to the first, but does have bundled parking. The probability shift thus isolates the unique association between bundled parking and vehicle ownership. So, for example, a stylized household in central city New York, Newark, or Philadelphia without bundled parking is more than twice as likely to be vehicle-free as a similar household with bundled parking. In Los Angeles and Chicago households without bundled parking are over three times as likely as their counterparts to be vehicle-free.

Table 2: Associations with being vehicle-free, US households, 2003-logit models

\begin{tabular}{|c|c|c|c|c|c|c|c|}
\hline & $\begin{array}{r}(1) \\
\text { National } \\
\end{array}$ & $\begin{array}{c}(2) \\
\text { New York } \\
\end{array}$ & $\begin{array}{c}(3) \\
\text { Los Angeles } \\
\end{array}$ & $\begin{array}{r}(4) \\
\text { Chicago } \\
\end{array}$ & $\begin{array}{r}(5) \\
\text { Newark } \\
\end{array}$ & $\begin{array}{c}(6) \\
\text { Philadelphia } \\
\end{array}$ & $\begin{array}{r}(7) \\
\text { Detroit } \\
\end{array}$ \\
\hline Bundled Parking & $\begin{array}{l}-1.2178 * * * \\
(0.0598)\end{array}$ & $\begin{array}{l}-1.3016^{* * *} \\
(0.1333)\end{array}$ & $\begin{array}{l}-1.2103 * * * \\
(0.2283)\end{array}$ & $\begin{array}{l}-1.6937 * * * \\
(0.1735)\end{array}$ & $\begin{array}{l}-1.5790 * * * \\
(0.2690)\end{array}$ & $\begin{array}{l}-0.9868 * * * \\
(0.2066)\end{array}$ & $\begin{array}{l}-0.7681 * \\
(0.3388)\end{array}$ \\
\hline Household in Poverty & $\begin{array}{l}1.5467 * * * \\
(0.0464)\end{array}$ & $\begin{array}{l}1.1701 * * * \\
(0.1677)\end{array}$ & $\begin{array}{l}1.5177 * * * \\
(0.1475)\end{array}$ & $\begin{array}{l}1.5342 * * * \\
(0.1696)\end{array}$ & $\begin{array}{l}1.3392 * * * \\
(0.2764)\end{array}$ & $\begin{array}{l}1.5508 * * * \\
(0.2029)\end{array}$ & $\begin{array}{l}1.8176^{* * * *} \\
(0.2348)\end{array}$ \\
\hline Persons in Household & $\begin{array}{l}-0.6342 * * * \\
(0.0290)\end{array}$ & $\begin{array}{l}-0.4091 * * * \\
(0.0503)\end{array}$ & $\begin{array}{l}-0.3793 * * * \\
(0.0673)\end{array}$ & $\begin{array}{l}-0.3435 * * * \\
(0.0744)\end{array}$ & $\begin{array}{l}-0.4527 * * * \\
(0.1108)\end{array}$ & $\begin{array}{l}-0.5555^{* * * *} \\
(0.0875)\end{array}$ & $\begin{array}{l}-0.5593 * * * \\
(0.1267)\end{array}$ \\
\hline In Central City & $\begin{array}{l}0.4744 * * * \\
(0.0522)\end{array}$ & $\begin{array}{l}1.4333^{* * * *} \\
(0.1613)\end{array}$ & $\begin{array}{l}-0.0944 \\
(0.1458)\end{array}$ & $\begin{array}{l}0.7418 * * * \\
(0.1882)\end{array}$ & $\begin{array}{l}0.8245^{* *} \\
(0.2926)\end{array}$ & $\begin{array}{l}1.1683 * * * \\
(0.2195)\end{array}$ & $\begin{array}{l}0.4287 \\
(0.3166)\end{array}$ \\
\hline Proportion $\mathrm{HH}$ w/BA or Higher & $\begin{array}{l}-1.0535 * * * \\
(0.0676)\end{array}$ & $\begin{array}{l}-0.4381 * * \\
(0.1563)\end{array}$ & $\begin{array}{l}-1.1408 * * * \\
(0.2482)\end{array}$ & $\begin{array}{l}-1.4154 * * * \\
(0.2364)\end{array}$ & $\begin{array}{l}-1.5199 * * * \\
(0.4139)\end{array}$ & $\begin{array}{l}-0.7239 * * \\
(0.2771)\end{array}$ & $\begin{array}{l}-1.4288^{* *} \\
(0.5020)\end{array}$ \\
\hline Proportion HH Male & $\begin{array}{l}-0.5848 * * * \\
(0.0635)\end{array}$ & $\begin{array}{l}-0.5949 * * * \\
(0.1722)\end{array}$ & $\begin{array}{l}-1.1601 * * * \\
(0.2269)\end{array}$ & $\begin{array}{l}-0.8879 * * * \\
(0.2182)\end{array}$ & $\begin{array}{l}-1.7426^{* * *} \\
(0.3656)\end{array}$ & $\begin{array}{l}-0.5945^{*} \\
(0.2509)\end{array}$ & $\begin{array}{l}-0.3628 \\
(0.3097)\end{array}$ \\
\hline Proportion HH Children & $\begin{array}{l}0.8153^{* * *} \\
(0.1185)\end{array}$ & $\begin{array}{l}0.1455 \\
(0.2997)\end{array}$ & $\begin{array}{l}1.2008 * * \\
(0.3657)\end{array}$ & $\begin{array}{l}-0.3379 \\
(0.4341)\end{array}$ & $\begin{array}{l}0.7118 \\
(0.5876)\end{array}$ & $\begin{array}{l}0.8064 \\
(0.4624)\end{array}$ & $\begin{array}{l}0.4754 \\
(0.5405)\end{array}$ \\
\hline Proportion HH Foreign Born & $\begin{array}{l}0.6740 * * * \\
(0.0753)\end{array}$ & $\begin{array}{l}-0.0226 \\
(0.1570)\end{array}$ & $\begin{array}{l}1.1992 * * * \\
(0.1775)\end{array}$ & $\begin{array}{l}0.1140 \\
(0.2416)\end{array}$ & $\begin{array}{l}0.5939 \\
(0.3106)\end{array}$ & $\begin{array}{l}0.5698 \\
(0.4084)\end{array}$ & $\begin{array}{l}0.6960 \\
(0.5381)\end{array}$ \\
\hline Proportion HH Black & $\begin{array}{l}0.6416 * * * \\
(0.0557)\end{array}$ & $\begin{array}{l}0.4015^{* *} \\
(0.1456)\end{array}$ & $\begin{array}{l}0.7110^{* *} \\
(0.2180)\end{array}$ & $\begin{array}{l}0.7772 * * * \\
(0.1740)\end{array}$ & $\begin{array}{l}0.1848 \\
(0.3071)\end{array}$ & $\begin{array}{l}0.6257 * * \\
(0.1947)\end{array}$ & $\begin{array}{l}0.4892 \\
(0.3173)\end{array}$ \\
\hline Proportion HH Age 65 or More & $\begin{array}{l}0.6133 * * * \\
(0.0582)\end{array}$ & $\begin{array}{l}0.2617 \\
(0.1790)\end{array}$ & $\begin{array}{l}1.0198 * * * \\
(0.2153)\end{array}$ & $\begin{array}{l}0.4860 * \\
(0.2158)\end{array}$ & $\begin{array}{l}0.3486 \\
(0.3461)\end{array}$ & $\begin{array}{l}0.2334 \\
(0.2515)\end{array}$ & $\begin{array}{l}1.1541 * * * \\
(0.3042)\end{array}$ \\
\hline Year Structure Built & $\begin{array}{l}-0.0058 * * * \\
(0.0009)\end{array}$ & $\begin{array}{l}-0.0017 \\
(0.0025)\end{array}$ & $\begin{array}{l}-0.0025 \\
(0.0034)\end{array}$ & $\begin{array}{l}0.0014 \\
(0.0033)\end{array}$ & $\begin{array}{l}-0.0067 \\
(0.0050)\end{array}$ & $\begin{array}{l}-0.0046 \\
(0.0040)\end{array}$ & $\begin{array}{l}0.0039 \\
(0.0054)\end{array}$ \\
\hline
\end{tabular}


Table 2: Associations with being vehicle-free, US households, 2003- logit models (continued)

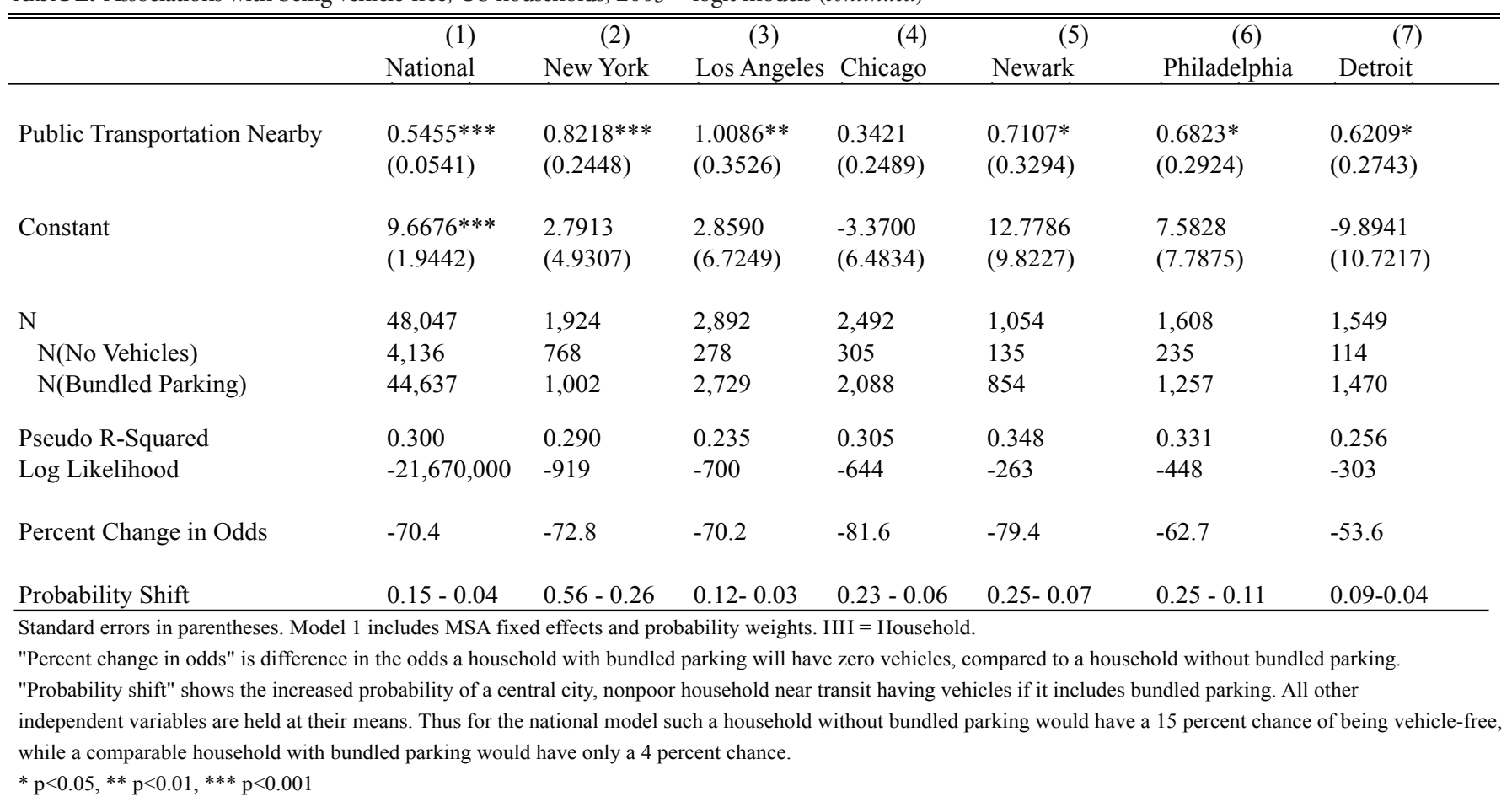

To address the possibility that these relationships between bundled parking and vehicle ownership are artifacts of other land-use attributes, the regressions in Table 3 control for the nearby built environment. Most of the controls are dichotomous variables indicating whether a particular land-use type (high-rise apartments, single-family homes, shops) is within a half-block of the housing unit. These controls have two potential problems. First, because they only cover a half-block, they are imperfect proxies for a neighborhood's built environment - a walkable mixed-use neighborhood could contain a half-block of detached single-family homes. In most instances, however, these variables probably give a reasonable sense of nearby land uses. Second, as mentioned earlier, some of these variables have substantial nonresponse, so using all of them in a regression drops the national sample size from over 48,000 to just over 12,500. Using all of the variables in the MSA regressions would be even more costly and drive the sample size down to a few hundred. To preserve sample size in the MSA regressions, I remove the variables indicating the presence of apartment buildings, which have the most missing data.

The land-use variables behave as expected, and not surprisingly when they are included the parking coefficients shrink. Households near high-rise apartments and shops and businesses are more likely to be vehicle-free, while housing units near detached single-family homes are less likely to be so. Yet even after accounting for these relationships, the association between bundled parking and vehicle ownership remains strong, except in the case of Detroit, where the coefficient stays negative but slips below conventional levels of statistical significance. Effect sizes also do not change much: the odds that a housing unit with bundled parking will be vehicle-free are 60 to 80 percent lower than the odds a household without bundled parking will. Finally, the probability shifts associated with bundled parking also remain large. The stylized households in these probability shifts are similar to those in Table 2, but here I further assume these households are near apartment buildings, parks, and shops and businesses, but not near single-family homes, industrial uses, or abandoned buildings. In the national sample, such households are twice as likely to be vehicle-free if they do not have bundled parking, and between two and three times as likely in the MSA samples. 
Table 3: Associations with being vehicle-free, US households with built environment atrributes 2003 - logit models

\begin{tabular}{|c|c|c|c|c|c|c|c|}
\hline & $\begin{array}{l}(1) \\
\text { National }\end{array}$ & $\begin{array}{l}(2) \\
\text { New York }\end{array}$ & $\begin{array}{l}(3) \\
\text { Los Angeles }\end{array}$ & $\begin{array}{l}(4) \\
\text { Chicago }\end{array}$ & $\begin{array}{l}(5) \\
\text { Newark }\end{array}$ & $\begin{array}{l}(6) \\
\text { Philadelphia }\end{array}$ & $\begin{array}{l}(7) \\
\text { Detroit }\end{array}$ \\
\hline Bundled Parking & $\begin{array}{l}-0.8678 * * * \\
(0.0862)\end{array}$ & $\begin{array}{l}-0.9756 * * * \\
(0.1576)\end{array}$ & $\begin{array}{l}-0.9880 * * * \\
(0.2509)\end{array}$ & $\begin{array}{l}-1.6539 * * * \\
(0.1838)\end{array}$ & $\begin{array}{l}-1.5734 * * * \\
(0.3305)\end{array}$ & $\begin{array}{l}-0.9505 * * * \\
(0.2342)\end{array}$ & $\begin{array}{l}-0.5334 \\
(0.3811)\end{array}$ \\
\hline Household in Poverty & $\begin{array}{l}1.5088 * * * \\
(0.0716)\end{array}$ & $\begin{array}{l}1.2035 * * * \\
(0.1910)\end{array}$ & $\begin{array}{l}1.6714 * * * \\
(0.1614)\end{array}$ & $\begin{array}{l}1.4950 * * * \\
(0.1837)\end{array}$ & $\begin{array}{l}1.3577 * * * \\
(0.3193)\end{array}$ & $\begin{array}{l}1.6155^{* * *} \\
(0.2199)\end{array}$ & $\begin{array}{l}1.7975 * * * \\
(0.2602)\end{array}$ \\
\hline Persons in Household & $\begin{array}{l}-0.5077 * * * \\
(0.0399)\end{array}$ & $\begin{array}{l}-0.4283 * * * \\
(0.0592)\end{array}$ & $\begin{array}{l}-0.3807 * * * \\
(0.0738)\end{array}$ & $\begin{array}{l}-0.3310 * * * \\
(0.0805)\end{array}$ & $\begin{array}{l}-0.5509 * * * \\
(0.1484)\end{array}$ & $\begin{array}{l}-0.5041 * * * \\
(0.0955)\end{array}$ & $\begin{array}{l}-0.5089 * * 2 \\
(0.1388)\end{array}$ \\
\hline In Central City & $\begin{array}{l}0.4361 * * * \\
(0.0761)\end{array}$ & $\begin{array}{l}1.2054 * * * \\
(0.1869)\end{array}$ & $\begin{array}{l}-0.1289 \\
(0.1605)\end{array}$ & $\begin{array}{l}0.7499 * * * \\
(0.2035)\end{array}$ & $\begin{array}{l}0.4958 \\
(0.3582)\end{array}$ & $\begin{array}{l}1.0827 * * * \\
(0.2592)\end{array}$ & $\begin{array}{l}0.4005 \\
(0.3445)\end{array}$ \\
\hline Proportion HH Male & $\begin{array}{l}-0.3996 * * * \\
(0.0881)\end{array}$ & $\begin{array}{l}-0.5147 * * \\
(0.1936)\end{array}$ & $\begin{array}{l}-1.0807 * * * \\
(0.2448)\end{array}$ & $\begin{array}{l}-0.9562 * * * \\
(0.2338)\end{array}$ & $\begin{array}{l}-2.0863 * * * \\
(0.4402)\end{array}$ & $\begin{array}{l}-0.6290 * \\
(0.2679)\end{array}$ & $\begin{array}{l}-0.3522 \\
(0.3341)\end{array}$ \\
\hline Proportion HH Children & $\begin{array}{l}0.5473 * * \\
(0.1780)\end{array}$ & $\begin{array}{l}0.2126 \\
(0.3633)\end{array}$ & $\begin{array}{l}1.0131 * \\
(0.4111)\end{array}$ & $\begin{array}{l}-0.2550 \\
(0.4775)\end{array}$ & $\begin{array}{l}1.2584 \\
(0.7711)\end{array}$ & $\begin{array}{l}0.5699 \\
(0.5147)\end{array}$ & $\begin{array}{l}0.0954 \\
(0.6247)\end{array}$ \\
\hline Proportion HH Foreign Born & $\begin{array}{l}0.4975 * * * \\
(0.1005)\end{array}$ & $\begin{array}{l}0.0101 \\
(0.1783)\end{array}$ & $\begin{array}{l}1.1882 * * * \\
(0.1935)\end{array}$ & $\begin{array}{l}-0.0819 \\
(0.2586)\end{array}$ & $\begin{array}{l}0.3067 \\
(0.3738)\end{array}$ & $\begin{array}{l}0.6154 \\
(0.4409)\end{array}$ & $\begin{array}{l}0.7110 \\
(0.6206)\end{array}$ \\
\hline Proportion HH Black & $\begin{array}{l}0.4722 * * * \\
(0.0795)\end{array}$ & $\begin{array}{l}0.5787 * * * \\
(0.1684)\end{array}$ & $\begin{array}{l}0.4690 \\
(0.2474)\end{array}$ & $\begin{array}{l}0.4893 * \\
(0.1954)\end{array}$ & $\begin{array}{l}0.4314 \\
(0.3557)\end{array}$ & $\begin{array}{l}0.5014^{*} \\
(0.2174)\end{array}$ & $\begin{array}{l}0.3587 \\
(0.3390)\end{array}$ \\
\hline Public Transportation Available & $\begin{array}{l}0.4254 * * * \\
(0.1031)\end{array}$ & $\begin{array}{l}0.9170 * * \\
(0.3476)\end{array}$ & $\begin{array}{l}1.4172 * * \\
(0.4891)\end{array}$ & $\begin{array}{l}0.6159 * \\
(0.3122)\end{array}$ & $\begin{array}{l}0.1496 \\
(0.3858)\end{array}$ & $\begin{array}{l}0.9855 * * \\
(0.3593)\end{array}$ & $\begin{array}{l}0.4914 \\
(0.3112)\end{array}$ \\
\hline $\begin{array}{l}\text { Unit Within } 1 / 2 \text { Block of: } \\
\text { Parking Lots }\end{array}$ & $\begin{array}{l}0.0890 \\
(0.0668)\end{array}$ & $\begin{array}{l}0.0837 \\
(0.1492)\end{array}$ & $\begin{array}{l}0.2436 \\
(0.1796)\end{array}$ & $\begin{array}{l}-0.0534 \\
(0.1866)\end{array}$ & $\begin{array}{l}0.3526 \\
(0.3086)\end{array}$ & $\begin{array}{l}-0.0648 \\
(0.2187)\end{array}$ & $\begin{array}{l}0.2359 \\
(0.2974)\end{array}$ \\
\hline High-Rise Apartment Buildings & $\begin{array}{l}0.2357 * \\
(0.1044)\end{array}$ & & & & & & \\
\hline Apartment Buildings $<4$ Stories & $\begin{array}{l}-0.2362 * * \\
(0.0860)\end{array}$ & & & & & & \\
\hline Apartment Buildings 4-6 Stories & $\begin{array}{l}0.2399 * * \\
(0.0832)\end{array}$ & & & & & & \\
\hline Single Family Town- or Rowhouses & $\begin{array}{l}-0.1604 * \\
(0.0760)\end{array}$ & $\begin{array}{l}0.0800 \\
(0.1567)\end{array}$ & $\begin{array}{l}-0.1906 \\
(0.2062)\end{array}$ & $\begin{array}{l}0.1101 \\
(0.1805)\end{array}$ & $\begin{array}{l}0.1588 \\
(0.3220)\end{array}$ & $\begin{array}{l}-0.2661 \\
(0.2168)\end{array}$ & $\begin{array}{l}-0.1051 \\
(0.3581)\end{array}$ \\
\hline
\end{tabular}


Table 3: Associations with being vehicle-free, US households with built environment atrributes 2003 - logit models (continued)

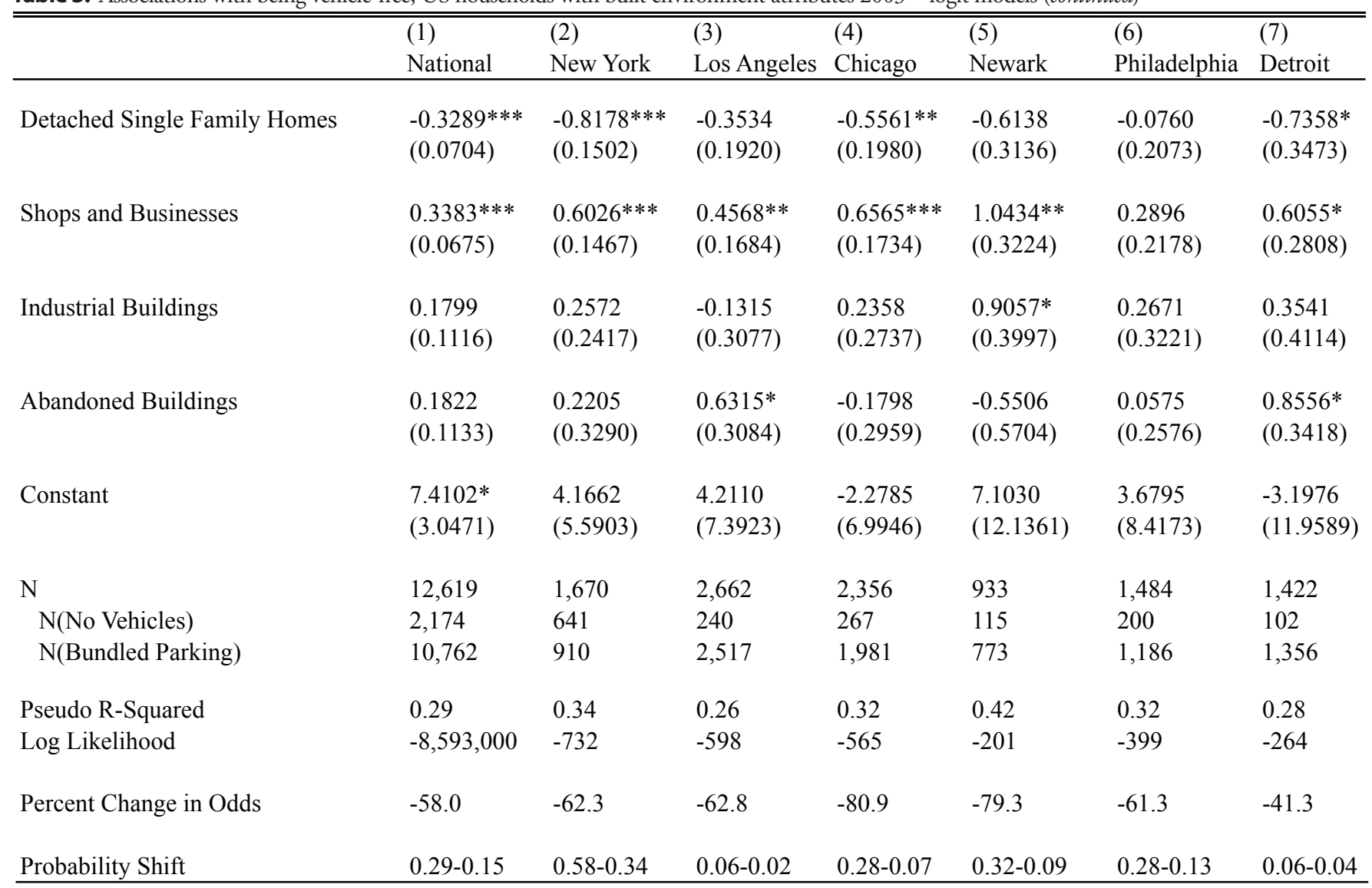

National model includes MSA fixed effects and is probability weighted. ${ }^{*} \mathrm{p}<0.05,{ }^{* *} \mathrm{p}<0.01,{ }^{* * *} \mathrm{p}<0.001$

All these results are robust to a variety of perturbations. The national results remain largely unchanged if I drop all observations from New York, and they do not change if I substitute household income for poverty status, or use dichotomous variables describing the demographic characteristics of the head of household rather than fractional variables describing all household members (e.g., use an indicator showing that the head of household is foreign born rather than a fraction of the household that is foreign born). Re-estimating the MSA regressions using every built-environment variable does not meaningfully change the results, though it greatly shrinks the sample sizes. Re-estimating the regressions with full land-use controls as Poisson models (with the dependent variable being the number of household vehicles) still yields a parking coefficient that is large, negative, and statistically significant. The national sample coefficients from these regressions suggest that a change from unbundled to bundled parking is associated with a 33 percent increase in the count of household vehicles. ${ }^{3}$

In sum, bundled parking has a strong association with vehicle ownership. Does it have similar associations with vehicle use? The AHS's only measure of vehicle use is commute mode-do commuters drive to work? Commuting is, on one hand, a poor proxy for overall vehicle use, since commuting is a small minority of both total driving and total travel. Commutes, however, are arguably of disproportionate importance since they tend to occur at peak hours and contribute disproportionately to congestion.

Bundled parking might influence commute decisions in two ways. The first and most obvious path is through vehicle ownership; if households with bundled parking are more likely to own vehicles, then commuters in those households should be more likely to drive. Yet bundled parking might also encour-

${ }^{3}$ All these specifications are available on request. 
age driving over and above its influence on vehicle ownership; vehicle-owning commuters with bundled parking might be more likely to drive than vehicle-owning commuters without it. For example, if people without bundled parking must search for street spaces whenever they return home, driving becomes less convenient and alternative modes become more attractive.

Table 4 shows the bundled parking coefficients from 24 regressions analyzing the commute decision to drive alone. While all the regressions include controls, to save space the table shows only the parking coefficients and their standard errors. For the nation and the six MSAs, I run four regressions apiece. The first two regressions are Poisson models analyzing the number of drivers in the household (with a control for the number of commuters) while the second two analyze the fraction of household commuters who drive. Because this fraction varies between zero and one and has a high mean (0.9), I estimate these regressions as generalized linear models with logit links, rather than as ordinary least squares (Papke and Woolridge 1996). (As I show later, however, estimating these regressions as ordinary least square models does not meaningfully change the results). The third and fourth sets of regressions are identical to the first two, but analyze only households with vehicles.

Table 4: Associations between bundled parking and driving to work, 2003-Poisson and generalized linear models (GLM)

\begin{tabular}{|c|c|c|c|c|c|c|c|}
\hline \multirow{2}{*}{$\begin{array}{l}\text { Location, Dependent Variable and } \\
\text { Regression Form }\end{array}$} & \multicolumn{3}{|c|}{ Bundled Parking - All Households } & \multicolumn{4}{|c|}{ Bundled Parking - HHs with Vehicles } \\
\hline & Coefficient & Std Error & $\mathrm{N}$ & Coefficient & Std Error & $\mathrm{N}$ & $\mathrm{N}($ Unbundled) \\
\hline \\
\hline Poisson - Drivers & $0.1763 * * *$ & $(0.0269)$ & 9,036 & $0.0488^{*}$ & $(0.0198)$ & 8,124 & 796 \\
\hline GLM -Fraction of Commuters Who Drive & $0.5826^{* * *}$ & $(0.0792)$ & 9,036 & $0.5016^{*}$ & $(0.2028)$ & 8,124 & 796 \\
\hline \multicolumn{8}{|l|}{ New York (52\% Bundled Parking) } \\
\hline Poisson - Drivers & $0.4494 * * *$ & 0.1109 & 1,130 & 0.1992 & $(0.1143)$ & 775 & 229 \\
\hline GLM -Fraction of Commuters Who Drive & $0.7833 * * *$ & 0.1668 & 1,130 & $0.5016^{*}$ & $(0.2028)$ & 775 & 229 \\
\hline \multicolumn{8}{|l|}{ Los Angeles (94\% Bundled Parking) } \\
\hline Poisson - Drivers & 0.2061 & 0.2244 & 2,064 & 0.0303 & $(0.1070)$ & 1,968 & 84 \\
\hline GLM -Fraction of Commuters Who Drive & $0.4514 *$ & 0.0814 & 2,064 & -0.1474 & $(0.3039)$ & 1,968 & 84 \\
\hline \multicolumn{8}{|l|}{ Chicago (83\% Bundled Parking) } \\
\hline Poisson - Drivers & 0.2353 & 0.0814 & 1,721 & 0.0868 & $(0.0830)$ & 1,613 & 183 \\
\hline GLM -Fraction of Commuters Who Drive & $0.7631 * * *$ & $(0.1537)$ & 1,721 & 0.2765 & $(0.1788)$ & 1,613 & 183 \\
\hline \multicolumn{8}{|l|}{ Northern NJ (83\% Bundled Parking) } \\
\hline Poisson - Drivers & $0.3045^{*}$ & $(0.1355)$ & 650 & 0.2031 & $(0.1355)$ & 602 & 80 \\
\hline GLM -Fraction of Commuters Who Drive & $0.9418^{* * *}$ & $(0.2525)$ & 650 & $0.7606 * *$ & $(0.2774)$ & 602 & 80 \\
\hline \multicolumn{8}{|l|}{ Philadelphia (77\% Bundled Parking) } \\
\hline Poisson - Drivers & 0.1251 & $(0.0992)$ & 1,064 & 0.0543 & $(0.1007)$ & 979 & 146 \\
\hline GLM -Fraction of Commuters Who Drive & $0.6542 * *$ & $(0.2157)$ & 1,064 & $0.5956^{*}$ & $(0.2526)$ & 979 & 146 \\
\hline \multicolumn{8}{|l|}{ Detroit (94\% Bundled Parking) } \\
\hline Poisson - Drivers & -0.0459 & $(0.1512)$ & 960 & -0.0506 & $(0.1577)$ & 936 & 31 \\
\hline GLM -Fraction of Commuters Who Drive & -1.0846 & $(1.0352)$ & 960 & $-13.1105^{* * *}$ & $(0.3225)$ & 936 & 31 \\
\hline
\end{tabular}

$* \mathrm{p}<0.05, * * \mathrm{p}<0.01, * * * \mathrm{p}<0.001$

Notes: National regressions include controls for: poverty status, transit availability, central city location,structure built before 1920, share of household male, share with a BA or higher, share under age 18, share foreign born, share black, and share 65 or older. Also proximity to parking lots, high and mid-rise apartments, parks, shops,single family homes, industrial uses and abandoned buildings. MSA regressions do not control for high- or mid-rise housing.

GLM regressions include robust standard errors, and are binomial family with logit links. Poisson regressions control for number of commuters in the household. National regressions include MSA fixed effects and probability weights. N(Unbundled) shows number of households with vehicles that lack bundled parking. 
When analyzing all households, bundled parking has a strong and positive association with commuters' decisions to drive. Much of this association, however, appears to result from bundled parking's association with vehicle ownership. When the sample is restricted to households that own vehicles, bundled parking's association with automobile commuting becomes more ambiguous. Although 12 of the 14 coefficients are positive, only five are statistically significant (one Detroit coefficient, curiously, is negative and statistically significant — perhaps because, as the far right column shows, almost all vehicle-owning households in Detroit have bundled parking). Some of the ambiguity may stem from omitted variables. Both the availability of parking at work and the availability of street parking at home will influence commuters' decisions to drive, but the AHS has no metrics that capture these attributes. The regressions might also be confounded by self-selection. A household without bundled parking that nevertheless owns vehicles might be composed of people with a strong unobserved preference for driving, and my inability to measure this preference might result in parking coefficients that are biased downward (I discuss self-selection more below). In sum the evidence that bundled parking is associated with more drive commuting is suggestive, but not definitive.

\subsection{Bundled parking and residential self-selection}

The regressions above show a strong association between bundled parking and vehicle ownership, but cannot show whether that association arises from changes in housing consumption, changes in vehicle ownership preferences, or both. This is the residential self-selection problem: People who would otherwise own vehicles might choose not to when confronted with the cost of unbundled parking, but housing without bundled parking might simply be more attractive to people who neither owned nor wanted vehicles to begin with. In the former case, unbundled parking would reduce overall vehicle ownership, while in the latter case it would only redistribute vehicle-free people toward housing that matches their preferences. In short, if travel preferences influence housing choices more than housing choices influence travel preferences, then the regressions will overestimate bundled parking's impact on vehicle ownership. ${ }^{4}$

In general, three conditions must hold for residential self-selection to overestimate the built environment's impact on travel: self-selectors must search for housing based primarily on their travel preferences; they must find such housing; and, if they do not find such housing, they must not travel their preferred way-self-selectors, in other words, must be more sensitive to the built environment than others (Chatman 2009; Cao and Chatman 2013). Because these assumptions are strong, many studies that control for self-selection find that its impacts are real but modest, and in some instances, find that self-selection underestimates the built environment's influence (Chatman 2009).

For the purposes of this article, the self-selection hypothesis assumes that people who do not want to own vehicles will a) search for housing without bundled parking, b) find that housing, and c) if they cannot find that housing, choose to own a vehicle. (If they did otherwise-chose not to own vehicles even after settling for housing with bundled parking - their actions would create an artificially positive correlation between being vehicle-free and having bundled parking, and thus underestimate bundled parking's impact on vehicle ownership).

These assumptions are difficult to examine directly. It is particularly hard to know why people choose their housing unit or neighborhood, absent surveys specifically designed to elicit this information (e.g., Chatman 2009). The AHS asks a subsample of "recent movers"-people who changed housing in the previous two years - why they chose their neighborhood and home. Table 5 shows their answers. Contrary to the self-selection hypothesis, travel and parking preferences are generally absent from these responses. Respondents chose housing primarily for financial and design reasons, and while travel is implicitly important in neighborhood choice-respondents want proximity to jobs and ame-

${ }^{4}$ For a general discussion of self-selection see van Wee (2009). 
nities - particular travel modes go largely unmentioned (the exception being the roughly 1 percent of respondents who chose their neighborhood primarily to be close to public transportation).

Table 5: Reported reasons for choosing neighborhood and home, recent movers 2003

\begin{tabular}{lrrlrr}
\hline \hline Choice of Neighborhood & Freq. & Percent & Choice of Home & Freq. & Percent \\
\hline Convenience to Job & 2,188 & 19.6 & Financial Reasons & 3,243 & 28.8 \\
Close to Friends and Relatives & 1,791 & 16 & Design/Layout of Rooms & 2,080 & 18.5 \\
For Housing Unit & 1,768 & 16 & Other Reasons & 1,959 & 17.4 \\
For Aesthetics & 1,710 & 15.3 & For Size & 1,567 & 13.9 \\
Good Schools & 749 & 6.7 & Only Home Available & 596 & 5.3 \\
All Reasons Equal & 306 & 2.7 & Yard/Trees/View & 548 & 4.9 \\
Close to Leisure Activity & 251 & 2.3 & Quality of Construction & 415 & 4.7 \\
Close to Public Transportation & 139 & 1.2 & Exterior Appearance & 415 & 3.7 \\
Public Services & 113 & 1 & All Reasons Equal & 401 & 3.6 \\
Other Reason & 2,272 & 20 & For Kitchen & 51.4 & 0.5 \\
& & & & & 11,275 \\
Total & 11,287 & 101 & & 101 \\
\hline
\end{tabular}

Source: American Housing Survey, 2003. Columns sum to over 100 due to rounding.

These tabulations are not, of course, conclusive. People might still be searching for housing based on their travel preferences. The survey was not designed to identify transportation-based self-selection, and almost a fifth of respondents chose "other reason," which might include preferences about parking or vehicle ownership. Further, people might search for housing that matches their travel preferences but not report doing so, because their travel preferences correlate closely with other search criteria. For example, perhaps searching for a well-designed home convenient to one's job almost automatically implies a home that meets one's travel preferences. If so, the absence of travel modes from the responses may not be meaningful.

At the same time, however, this sort of correlation between travel preferences and other desired amenities might be stronger for people who want to drive, because many desirable amenities may be correlated with environments designed around automobiles. ${ }^{5}$ For example, many people want newer, larger suburban housing, but housing without parking tends to be in older structures in center cities, so selecting on the desire for unbundled parking might involve sacrificing large homes, yards, and other suburban amenities. Fischel (2002) argues that many suburban jurisdictions maintain quality public services by enforcing large minimum lot sizes, which simultaneously excludes lower-income people, increases minimum tax bills, and pushes land uses apart. One result is a strong correlation between good schools, low crime rates, and low-densities that encourage driving (Fischel 2002). The upshot is that people who want vehicles might face fewer tradeoffs in their housing search than people who prefer other modes.

Assume for the moment, however, that people do prioritize bundled parking when they search for housing. The second condition of the self-selection hypothesis is that they find such housing. This condition is also difficult to meet; most housing in most parts of the country has bundled parking. Table 6 uses data from the AHS metropolitan surveys, the 2000 Decennial Census, and the 2006 American Community Survey to show the scarcity and geographic unevenness of housing without bundled parking. Unbundled parking is disproportionately located in older buildings of MSAs in the Northeast and Midwest. Chicago, Newark, New York and Philadelphia together account for 11 percent of the US population and housing stock, but 40 percent of its housing without bundled parking. The New York MSA alone holds 4 percent of America's housing, but 24 percent of its housing without bundled parking.

\footnotetext{
${ }^{5}$ People who don't want vehicles might search for housing with parking because it increases property values, or because they want to use a garage as storage. In this case, the selection is uncorrelated with vehicle ownership preferences and might bias the association between bundled parking and vehicle ownership downward.
} 
Table 6: Availability of housing units without bundled parking, nation and six large metropolitan areas, 2003

\begin{tabular}{|c|c|c|c|c|c|c|c|}
\hline & UUS & Chicago & New York & Los Angeles & Detroit & Newark & Philadelphia \\
\hline MSA Share of US Population & $\mathrm{n} / \mathrm{a}$ & $3 \%$ & $4 \%$ & $3 \%$ & $2 \%$ & $2 \%$ & $2 \%$ \\
\hline MSA Share of US HUs w/ Unbundled Parking & $\mathrm{n} / \mathrm{a}$ & $6 \%$ & $25 \%$ & $2 \%$ & $1 \%$ & $4 \%$ & $5 \%$ \\
\hline Percent of HUs w/out Bundled Parking Built Before 1940 & $23 \%$ & $73 \%$ & $24 \%$ & $56 \%$ & $100 \%$ & $50 \%$ & $74 \%$ \\
\hline Percent of HUs 1999-2003 w/Unbundled Parking & $2 \%$ & $5 \%$ & $40 \%$ & $0 \%$ & $0 \%$ & $6 \%$ & $0 \%$ \\
\hline MSA Share of Housing Built 1999-2003 w/Unbundled Parking & $\mathrm{n} / \mathrm{a}$ & $6 \%$ & $77 \%$ & $0 \%$ & $0 \%$ & $6 \%$ & $0 \%$ \\
\hline
\end{tabular}

Sources: AHS microdata and summary data, national and metropolitan. American Community Survey, 2006 and US Census 2000.

Even these figures understate the difficulty of finding housing with unbundled parking. Most housing without bundled parking is in central cities, so consumers searching for suburban houses without bundled parking are unlikely to be successful. Housing without bundled parking also tends to be old. Only 25 percent of Philadelphia's housing predates $1940,{ }^{6}$ but this one-quarter of units accounts for three-quarters of the region's housing without bundled parking. In the Detroit MSA, all housing without bundled parking was built before 1940. In fact, anyone wanting new housing without bundled parking had best search in New York. In 2003, New York accounted for 1 percent of the nation's housing built in the previous four years but an astonishing 77 percent of such housing without bundled parking. In Los Angeles, Detroit, and Philadelphia, all surveyed units built from 1999 to 2003 had bundled parking.

One might argue that this scarcity reflects consumer preferences-developers would supply housing without bundled parking if people wanted it, so its absence suggests that most housing consumers want parking with their units. But the ubiquity of minimum parking requirements undermines this reasoning; while the prevalence of bundled parking could reflect consumer preferences, it could also reflect government mandates. Housing might include parking not because consumers wanted it but because the government required it. Over 86 percent of America's housing was built after 1939, and thus likely subject to parking requirements. It is surely no accident that New York, which has old housing stock and the country's lowest parking requirements, also has the nation's lowest share of bundled parking. And the history of minimum parking requirements suggests they arose because existing neighbors, not consumers, wanted new development to have off-street parking (Shoup 2005). Bundled parking's prevalence might therefore be as much a result of public fiat as it is of private choice.

\subsection{Tests for self-selection}

Bundled parking's uneven distribution across metropolitan areas suggests a path to controlling for selfselection: use MSA-level attributes that predict bundled parking as instrumental variables. This approach, similar to one employed by Brueckner and Largey (2008), assumes that while people might select houses based on their vehicle ownership preferences, most people are unlikely to select metropolitan areas for that reason. For example, when people without vehicles or the desire to acquire them move to the New York MSA, they choose city apartments instead of suburban homes. But preferences about vehicle ownership are unlikely to determine whether people live in New York rather than Phoenix or Indianapolis.

Is this assumption reasonable? The average American moves almost 12 times during his or her lifetime, ${ }^{7}$ but a large majority of these moves are within the same metropolitan area. In 2008, 37 percent of American adults had never lived outside their hometowns, and 57 percent had never left their home state (Taylor et al. 2008). Between 1995 and 2000, only 30 percent of metropolitan residents

\footnotetext{
${ }^{6}$ Census summary file data do not predate 1940 .

${ }^{7}$ https://www.census.gov/hhes/migration/about/cal-mig-exp.html
} 
who moved left their MSA, and in the 30 largest MSAs (a better approximation of the areas used in this analysis), the fraction is even lower: 26 percent. ${ }^{8}$ Thus during the time period I am analyzing, most Americans made housing choices that held their MSA constant. As for the minority of movers who entered a new MSA, the existing evidence suggests that first, a sizeable share come from outside the United States, and second, those who switch MSAs within the United States do so for family or employment reasons (Schachter, Franklin, and Perry 2003). Exigencies of work and accidents of birth, not preferences about driving, appear to be the primary determinants of metropolitan location.

This reasoning does not suggest that no one bases metropolitan location on travel preferences, only that most people don't. And if most people don't, then the MSA's share of housing with bundled parking will be correlated with the odds that any given housing unit in that MSA has bundled parking, but not correlated with anyone's unobserved desire to own vehicles — therefore satisfying the conditions for valid instruments.

I use two instruments: the MSA's share of housing with bundled parking, and its share of housing built before 1920. I construct these variables using summary data for the 2000-07 AHS metropolitan surveys. I use data from surveys before and after 2003, because the 2003 survey only has representative data for six MSAs. Using summary data from the surrounding years and then matching it to households in the 2003 survey allows me to use more than 30 MSAs and preserve sample size. Both variables suggest the overall abundance of residential parking, and thus predict the chances that a given housing unit includes parking. Yet neither should independently predict a household's vehicle ownership or decision to drive. Arguably the share of housing built before 1920 is unnecessary, as it is quite collinear with the share of housing without bundled parking $(\mathrm{r}=0.8)$. Nevertheless, I use two instruments, because doing so allows more accurate post-estimation tests. Instrumenting with the share of housing with bundled parking alone does not meaningfully change the regression results.

Table 7 shows two ordinary least square (OLS) regressions and two instrumental variables (IV) regressions. The regressions are linear, and the IV equations use two stage least squares, because IV estimation is extremely difficult when both the dependent variable and the endogenous regressor are dichotomous. In the first pair of regressions, the dependent variable is the number of vehicles per household. In the second pair, the dependent variable is the fraction of commuters in households with vehicles who choose to drive (similar to the second set of regressions in Table 4, but estimated as OLS rather than generalized linear models (GLM). The results suggest that much of bundled parking's effect is causal, and that if anything, self-selection is underestimating bundled parking's influence; the IV parameter estimates are consistently larger than the OLS estimates. More conservatively, the results suggest that at the least self-selection is not biasing the coefficients upward. Post-estimation tests show Wald scores substantially higher than the minimum Eigen values (this is so even when robust standard errors are used), offering some reassurance that the instruments are valid. (I show the first stage regression results in the Appendix).

\footnotetext{
${ }^{8}$ See http://www.census.gov/population/www/cen2000/migration/metxmet/
} 
Table 7: Associations with vehicle ownership and driving, OLS and IV estimates, 2003

\begin{tabular}{|c|c|c|c|c|}
\hline & \multicolumn{2}{|c|}{ Vehicles Per Person } & \multicolumn{2}{|c|}{ Drivers Per Commuter } \\
\hline & OLS & IV & OLS & IV \\
\hline Bundled Parking & $\begin{array}{l}0.207 * * * \\
(0.0167)\end{array}$ & $\begin{array}{l}0.610 * * * \\
(0.148)\end{array}$ & $\begin{array}{l}0.102 * * * \\
(0.0151)\end{array}$ & $\begin{array}{l}0.824 * * * \\
(0.180)\end{array}$ \\
\hline Household Income $(\$ 1,000 \mathrm{~s})$ & $\begin{array}{l}0.000114 \\
(0.0000810)\end{array}$ & $\begin{array}{l}0.000361 * * \\
(0.000130)\end{array}$ & $\begin{array}{l}-0.000106^{* *} \\
(0.0000398)\end{array}$ & $\begin{array}{l}-0.000450 * * \\
(0.000148)\end{array}$ \\
\hline Central City & $\begin{array}{l}-0.0447 * * * \\
(0.00984)\end{array}$ & $\begin{array}{l}-0.0412 * \\
(0.0168)\end{array}$ & $\begin{array}{l}-0.0251 * * * \\
(0.00700)\end{array}$ & $\begin{array}{l}0.00664 \\
(0.0152)\end{array}$ \\
\hline Proportion HH w/BA or Higher & $\begin{array}{l}0.154 * * * \\
(0.0145)\end{array}$ & $\begin{array}{l}0.170 * * * \\
(0.0218)\end{array}$ & $\begin{array}{l}-0.0590 * * * \\
(0.0109)\end{array}$ & $\begin{array}{l}-0.0302 \\
(0.0203)\end{array}$ \\
\hline Proportion HH Male & $\begin{array}{l}0.0984 * * * \\
(0.0158)\end{array}$ & $\begin{array}{l}0.102 * * * \\
(0.0250)\end{array}$ & $\begin{array}{l}-0.00490 \\
(0.0107)\end{array}$ & $\begin{array}{l}-0.00647 \\
(0.0215)\end{array}$ \\
\hline Proportion HH Children & $\begin{array}{l}-0.719^{* * *} \\
(0.0205)\end{array}$ & $\begin{array}{l}-0.732 * * * \\
(0.0323)\end{array}$ & $\begin{array}{l}0.0145 \\
(0.0149)\end{array}$ & $\begin{array}{l}0.0212 \\
(0.0284)\end{array}$ \\
\hline Proportion HH Foreign Born & $\begin{array}{l}-0.188^{* * * *} \\
(0.0149)\end{array}$ & $\begin{array}{l}-0.214^{* * * *} \\
(0.0238)\end{array}$ & $\begin{array}{l}-0.0202 \\
(0.0113)\end{array}$ & $\begin{array}{l}-0.0376^{*} \\
(0.0187)\end{array}$ \\
\hline Proportion HH Black & $\begin{array}{l}-0.0710 * * * \\
(0.0132)\end{array}$ & $\begin{array}{l}-0.0368 \\
(0.0215)\end{array}$ & $\begin{array}{l}0.0115 \\
(0.00949)\end{array}$ & $\begin{array}{l}0.0134 \\
(0.0182)\end{array}$ \\
\hline Proportion HH Age 65 or More & $\begin{array}{l}-0.248^{* * *} \\
(0.0176)\end{array}$ & $\begin{array}{l}-0.262 * * * \\
(0.0296)\end{array}$ & $\begin{array}{l}-0.0596 * * * \\
(0.0157)\end{array}$ & $\begin{array}{l}-0.0852 * * \\
(0.0306)\end{array}$ \\
\hline Year Structure Built & $\begin{array}{l}0.000429 * \\
(0.000213)\end{array}$ & $\begin{array}{l}-0.000693 \\
(0.000637)\end{array}$ & $\begin{array}{l}0.000929 * * * \\
(0.000172)\end{array}$ & $\begin{array}{l}-0.00120 \\
(0.000657)\end{array}$ \\
\hline Public Transit Available & $\begin{array}{l}-0.0463 * * * \\
(0.0114)\end{array}$ & $\begin{array}{l}-0.0868 * * * \\
(0.0234)\end{array}$ & $\begin{array}{l}-0.0147 \\
(0.00762)\end{array}$ & $\begin{array}{l}-0.0322 * \\
(0.0148)\end{array}$ \\
\hline $\begin{array}{l}\text { Unit Within 1/2 Block of: } \\
\quad \text { Parking Lots }\end{array}$ & $\begin{array}{l}-0.0224 * \\
(0.0101)\end{array}$ & $\begin{array}{l}-0.0597 * * * \\
(0.0175)\end{array}$ & $\begin{array}{l}-0.0280 * * * \\
(0.00815)\end{array}$ & $\begin{array}{l}-0.0623 * * * \\
(0.0160)\end{array}$ \\
\hline High-Rise Apartment Building & $\begin{array}{l}-0.0996 * * * \\
(0.0212)\end{array}$ & $\begin{array}{l}-0.0194 \\
(0.0340)\end{array}$ & $\begin{array}{l}-0.105 * * * \\
(0.0210)\end{array}$ & $\begin{array}{l}0.00347 \\
(0.0374)\end{array}$ \\
\hline Apartments $<4$ Stories & $\begin{array}{l}0.0186 \\
(0.0103)\end{array}$ & $\begin{array}{l}0.0157 \\
(0.0181)\end{array}$ & $\begin{array}{l}0.00562 \\
(0.00804)\end{array}$ & $\begin{array}{l}0.0219 \\
(0.0162)\end{array}$ \\
\hline Town Houses and Row House & $\begin{aligned} & 0.0342 * \\
& (0.0150)\end{aligned}$ & $\begin{array}{l}-0.00143 \\
(0.0279)\end{array}$ & $\begin{array}{l}0.0368 * \\
(0.0160)\end{array}$ & $\begin{array}{l}-0.0321 \\
(0.0257)\end{array}$ \\
\hline Single Family Homes & $\begin{array}{l}0.0874 * * * \\
(0.0104)\end{array}$ & $\begin{array}{l}0.0457 * \\
(0.0198)\end{array}$ & $\begin{array}{l}0.0160 \\
(0.00858)\end{array}$ & $\begin{array}{l}-0.0151 \\
(0.0178)\end{array}$ \\
\hline Parks & $\begin{array}{l}-0.000387 \\
(0.00986)\end{array}$ & $\begin{array}{l}0.00292 \\
(0.0170)\end{array}$ & $\begin{array}{l}-0.00353 \\
(0.00821)\end{array}$ & $\begin{array}{l}-0.0101 \\
(0.0152)\end{array}$ \\
\hline Apartments 4-6 Stories & $\begin{array}{l}-0.0706^{* * * *} \\
(0.0150)\end{array}$ & $\begin{array}{l}-0.000942 \\
(0.0245)\end{array}$ & $\begin{array}{l}-0.0721 * * * \\
(0.0130)\end{array}$ & $\begin{array}{l}-0.00999 \\
(0.0246)\end{array}$ \\
\hline & & & 0.0109 & -0.0280 \\
\hline
\end{tabular}


Table 7: Associations with vehicle ownership and driving, OLS and IV estimates, 2003 (continued)

\begin{tabular}{|c|c|c|c|c|}
\hline & \multicolumn{2}{|c|}{ Vehicles Per Person } & \multicolumn{2}{|c|}{ Drivers Per Commuter } \\
\hline & OLS & IV & OLS & IV \\
\hline Industrial Buildings & $\begin{array}{l}-0.0298 \\
(0.0191)\end{array}$ & $\begin{array}{l}-0.0215 \\
(0.0382)\end{array}$ & $(0.0150)$ & $(0.0302)$ \\
\hline Abandoned Buildings & $\begin{array}{l}-0.0294 \\
(0.0171)\end{array}$ & $\begin{array}{l}0.00444 \\
(0.0330)\end{array}$ & $\begin{array}{l}-0.0152 \\
(0.0165)\end{array}$ & $\begin{array}{l}0.0148 \\
(0.0379)\end{array}$ \\
\hline Shops and Businesses & $\begin{array}{l}-0.0503 * * * \\
(0.00998)\end{array}$ & $\begin{array}{l}-0.00944 \\
(0.0163)\end{array}$ & $\begin{array}{l}-0.0125 \\
(0.00720)\end{array}$ & $\begin{array}{l}0.0335^{*} \\
(0.0146)\end{array}$ \\
\hline Constant & $\begin{array}{l}-0.119 \\
(0.418)\end{array}$ & $\begin{array}{l}1.781 \\
(1.147)\end{array}$ & $\begin{array}{l}-0.979 * * \\
(0.332)\end{array}$ & $\begin{array}{l}2.623^{*} \\
(1.156)\end{array}$ \\
\hline $\mathrm{N}$ & 12,767 & 4,958 & 8124 & 3337 \\
\hline R-Squared & 0.23 & 0.17 & 0.091 & . \\
\hline Dependent Variable Mean & 0.70 & 0.72 & 0.87 & 0.87 \\
\hline $\begin{array}{l}\text { First Stage Diagnostics } \\
\text { First Stage Partial } \mathrm{R}^{2} \\
\text { Minimum Eigenvalue } \\
\text { 2SLS Nominal Wald 5\% Test }\end{array}$ & & $\begin{array}{l}0.04 \\
93 \\
19.93 \\
\end{array}$ & & $\begin{array}{l}0.03 \\
56 \\
19.93 \\
\end{array}$ \\
\hline $\begin{array}{l}\text { Notes: Standard errors in parenthese } \\
\text { OLS= Ordinary Least Square. IV = } \\
\text { is instrumented with MSA share of } \\
\text { Regressions are probability-weighte } \\
\text { to generate eigen values. "Drivers pe }\end{array}$ & $\begin{array}{l}\mathrm{p}<0.05,{ }^{* *} \mathrm{p}<\mathrm{c} \\
\text { Imental variab } \\
\text { ng with bundle } \\
\text { t some postesti } \\
\text { nmuter" mode }\end{array}$ & $\begin{array}{l}01, * * * \mathrm{p}<0.00 \\
\text { s (two-stage le } \\
\text { parking, and } \mathrm{x} \\
\text { ation tests are } \\
\text { only examine }\end{array}$ & $\begin{array}{l}\text { t squares). } \\
\text { A share of h } \\
\text { timated with } \\
\text { useholds wi }\end{array}$ & $\begin{array}{l}\text { hold bundled parking } \\
\text { ng built before } 1920 . \\
\text { weights in order } \\
\text { hicles, and use }\end{array}$ \\
\hline
\end{tabular}

One can quarrel with these estimates on a number of grounds. To use the IV regressions, I have drawn in data from other AHS surveys and changed the functional form of the regressions. Additionally, the share of housing built before 1920 might be correlated with aspects of the built environment other than the availability of parking (such as the width of streets) that might influence vehicle ownership decisions (although, again, estimating the regressions without this instrument does not change them, and in fact the bundled parking coefficient grows). Lastly, one might object, with some reason, that IV approaches are prone to enough problems to make them generally unpersuasive (for a discussion see Murray 2006).

To address these concerns, I carry out four further tests for self-selection. The first of these tests uses the recent mover subsample. To address the possibility I raised earlier-that some self-reported search criteria may be highly correlated with preferences about vehicle ownership-I estimate two regressions that include binary variables for every stated reason for choosing a neighborhood or home (Table 8, Models 1 and 2). The bundled parking coefficients remain large and statistically significant. In my second test, I restrict the sample to the roughly 5 percent of respondents who say their home was the only one available (Table 8, Model 3). Assuming this response is truthful, these respondents were not able to choose their home, which renders self-selection moot. ${ }^{9}$ Of these homes, 89 percent had bundled parking — essentially the same share as US households overall. The bundled parking coefficient is again robust, and the odds that households with bundled parking will be vehicle-free are 60 percent lower than the odds for households without bundled parking.

\footnotetext{
${ }^{9}$ Over 30 percent of respondents who said no other homes were available were poor, suggesting that their choices may well have been highly constrained.
} 
Table 8: Associations with vehicle ownership, recent movers by reason for choosing home and neighborhood, 2003

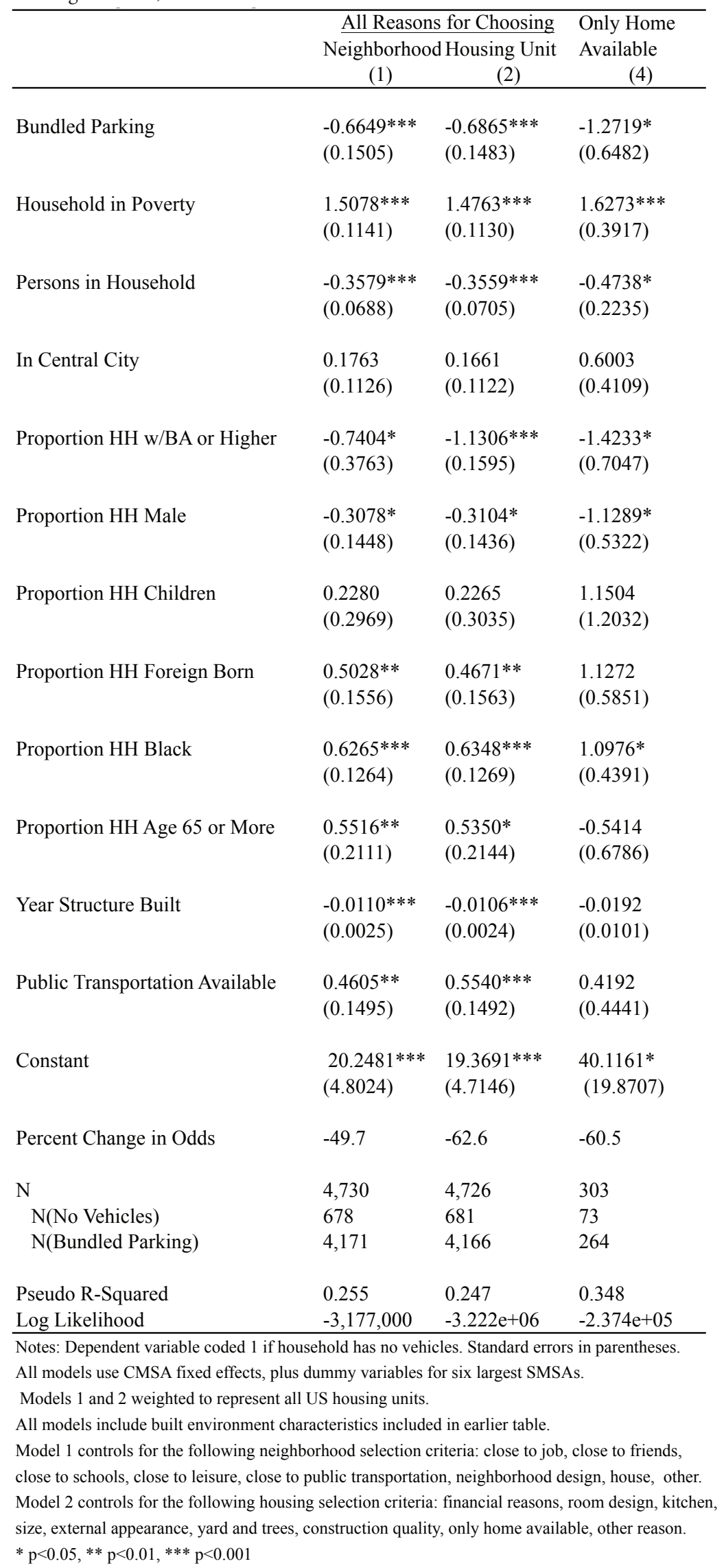


The third test for self-selection restricts the sample to rent-regulated housing in New York City (Table 9). Rent-regulated units offer both lower prices and greater tenant rights (such as protections from eviction) than market-rate housing, ${ }^{10}$ and these submarket prices might misallocate housing by creating large penalties for moving. People reluctant to give up steeply discounted housing might keep units with some attributes they do not value, and not seek housing with attributes they value highly (Glaeser and Luttmer 2003). For instance, a couple with grown children might not downsize to a smaller apartment if doing so requires exchanging their lower-priced regulated apartment for a smaller unregulated unit that costs more. Yet an observer unaware of the rent regulation might wrongly conclude that this couple strongly values extra space; the price control upsets the normal relationship between amenities and prices, and by selecting for price people in rent-regulated units might not be selecting along other desired amenities, including whether the unit includes parking. Some people who value parking highly might forego it to keep cheap rent, and vice-versa.

The regressions show that the odds of unit with bundled parking being vehicle-free are about 70 percent lower than the odds for housing without bundled parking. However, because the sample size is small, these rent-control regressions do not include full built-environment controls. Further, unlike all other samples in this article, rent-regulated units overwhelmingly do not have bundled parking — only 10 percent include a parking space. Thus while the relationship between bundled parking and vehicle ownership remains robust and consistent in these equations, it may provide a less persuasive test for self-selection.

\footnotetext{
${ }^{10}$ See New York City Housing and Vacancy Survey (2002).
} 
Table 9: Associations with being vehicle-free, rent-regulated households in New York City, 2003

\begin{tabular}{|c|c|c|}
\hline & $(1)$ & $(2)$ \\
\hline Bundled Parking & $\begin{array}{l}-1.248 * \\
(0.519)\end{array}$ & $\begin{array}{l}-1.282 * \\
(0.541)\end{array}$ \\
\hline Household in Poverty & $\begin{array}{l}0.659 \\
(0.431)\end{array}$ & $\begin{array}{l}0.568 \\
(0.441)\end{array}$ \\
\hline Persons in Household & $\begin{array}{l}-0.354 * \\
(0.144)\end{array}$ & $\begin{array}{l}-0.352 * \\
(0.151)\end{array}$ \\
\hline Proportion of HH Male & $\begin{array}{l}-0.326 \\
(0.469)\end{array}$ & $\begin{array}{l}-0.422 \\
(0.490)\end{array}$ \\
\hline Proportion Children & $\begin{array}{l}-0.630 \\
(0.848)\end{array}$ & $\begin{array}{l}-0.646 \\
(0.875)\end{array}$ \\
\hline Proportion Immigrant & $\begin{array}{l}-0.333 \\
(0.439)\end{array}$ & $\begin{array}{l}-0.364 \\
(0.454)\end{array}$ \\
\hline Proportion Age 65 or Over & $\begin{array}{l}1.119 * \\
(0.516)\end{array}$ & $\begin{array}{l}0.995 \\
(0.523)\end{array}$ \\
\hline Unit Near Single Family Homes & & $\begin{array}{l}-0.870 * \\
(0.372)\end{array}$ \\
\hline Unit Near Shops and Businesses & & $\begin{array}{l}-0.440 \\
(0.432)\end{array}$ \\
\hline Constant & $\begin{array}{l}1.490 * * * \\
-0.441\end{array}$ & $\begin{array}{l}2.249 * * * \\
-0.626\end{array}$ \\
\hline Percent Change in Odds & -71.3 & -72.3 \\
\hline $\mathrm{N}$ & 194 & 189 \\
\hline N(No Vehicles) & 135 & 132 \\
\hline N(Bundled Parking) & 20 & 20 \\
\hline Pseudo R-Squared & 0.123 & 0.153 \\
\hline Log Likelihood & -104.5 & -97.96 \\
\hline
\end{tabular}

The final test for self-selection restricts the sample to public housing units. People cannot self-select if they cannot choose their own housing, and some US public housing authorities sort people into housing in procedures that, at least with respect to parking, give them no choices. With the help of a research assistant, I reviewed literature about tenant selection in public housing and contacted four large housing authorities (Los Angeles, New York, Chicago, and Philadelphia) to ask both how they assigned their units and whether their units included parking. I found three common factors in these procedures: a quasi-random assignment procedure based primarily on the number of bedrooms; housing locations that prevent every unit from having bundled parking; and long waitlists that discourage people from turning down units they have been assigned. These factors in combination often make bundled parking 
exogenous to housing choices.

The Los Angeles housing authority, for example, explains its unit assignment as follows (emphasis added):

Applicants will be provided up to three offers of units at three different sites. Offers are generated at random based on the vacancies ready for occupancy at the time of the offers. Applicants do not get to pick their site. ${ }^{11}$

Only one public housing site in Los Angeles includes parking with each unit. Every other site has some parking but not enough for all units. Because applicants are assigned sites and units by chance, some receive housing without parking, regardless of whether they own or want vehicles. In most sites, residents must apply separately for parking permits, and when there are more applications than permits, the site holds a lottery. Tenants who don't secure parking through the lottery must either find off-street parking elsewhere or (more likely) use spaces on the street. Philadelphia and Chicago have similar systems. In both cities, parking for public housing is first come, first served, meaning some residents get off-street spaces while others park on the street.

Would-be drivers sorted into housing without parking could ask for different units or try to transfer. But long waitlists discourage either option. Rejecting offers puts applicants back into queues, and public housing waitlists have long been at crisis levels. In 1999, the US Department of Housing and Urban Development (HUD) reported that the average wait time across housing authorities nationwide was 33 months, and in some cities much longer. New York City's wait list was eight years, while Oakland's was six, and Cleveland's five. Los Angeles' 2003 waitlist was three years (Curry 2004). Severe shortages were not unique to large cities; suburban housing authorities in Alabama and Minnesota also had long queues (Curry 2004). These conditions make transfers uncommon. Jacob (2004), after interviewing Chicago Housing Authority (CHA) officials, reported that:

With roughly 30,000 families on the waiting list for CHA housing, waiting times of 7-8 years for public housing...are not uncommon. When families reach the top of the list, they are assigned units based on bedroom size and availability. Prospective tenants can reject an offer and place their name on a waiting list for a particular development, but this rarely occurs in practice because the site-specific waiting lists are often longer than the general CHA list. Because of the high demand for public housing services and the physical deterioration of many buildings, there are almost no transfers..."

Table 10 shows three regressions. The first equation examines all public housing units in the AHS. The second is restricted to public housing units in the four large MSAs whose central city procedures and backlogs I examined: New York, Los Angeles, Chicago, and Philadelphia (shortages in the central city often spill over into suburban public housing authorities). The third equation analyzes only the units in those central cities. In all equations, the coefficients on bundled parking remain large, negative, and statistically significant, and suggest that the odds of a household being vehicle-free are 60 to 75 percent lower for housing units with bundled parking than without.

\footnotetext{
${ }^{11}$ http://www.hacla.org/apply-public-housing/
} 
Table 10: Associations with having zero vehicles, public housing households, 2003

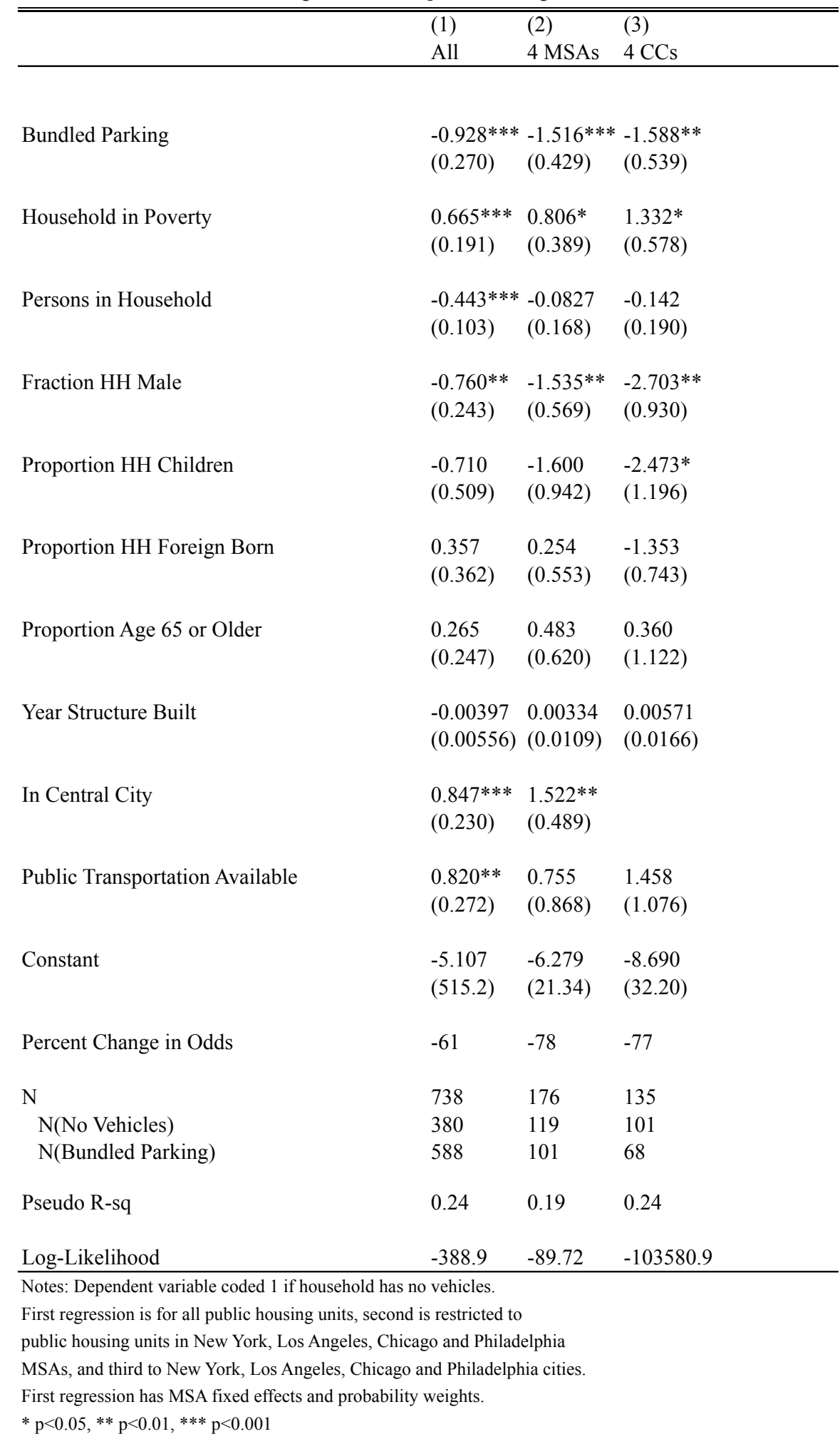




\section{Conclusion}

This article suggests that bundled parking strongly predicts vehicle ownership, both across the nation and within six large MSAs. It further shows a strong albeit less stable association between bundled parking and vehicle owners' decisions to drive to work. These associations persist in the face of demographic and land-use controls and are robust to a variety of tests for residential self-selection. To be clear, with cross-sectional data no approach perfectly controls for self-selection. But five different approaches to controlling for it yield consistent results, all of which suggest a statistically and economically significant impact of bundled parking on vehicle ownership. In general, the estimates suggest that households with bundled parking are 60 to 80 percent less likely to be vehicle-free than households with bundled parking.

In sum, there is reason to believe that bundled parking causes additional vehicle ownership; at the margin, hiding the cost of parking in the price of housing leads more people to own vehicles. The results suggest that reducing or eliminating minimum parking requirements—which will likely reduce the incidence of bundled parking — will also reduce vehicle ownership and by extension vehicle use. 


\section{References}

Bento, A., M. Cropper, M. Moborak, and K. Vinha. 2005. The impact of urban spatial structure on travel demand in the United States. Review of Economics and Statistics 87(3): 466-478.

Boarnet, M. 2011. A broader context for land use and travel behavior. Journal of the American Planning Association 77(3): 197-213.

Boarnet, M., and R. Crane. 2001. Travel by Design. Oxford, UK: Oxford University Press.

Brueckner, J., and A. Largey. 2008. Social interaction and urban sprawl. Journal of Urban Economics 64(1): 18-34.

Cervero, R., and R. Ewing. 2010. Travel and the built environment: A meta-analysis. Journal of the American Planning Association 76(3): 265-94.

Cao, X., P. Mokhtarian, and S. Handy. 2007. Cross-sectional and quasi-panel explorations of the connection between the built environment and auto ownership. Transportation Research A 39: 830-857.

Cao, X., and D. Chatman. 2012. How will land use policies affect travel? Transportation Research Board 91st Annual Meeting, January 22-26, Washington, DC.

Chester, M., A. Horvath, and S. Madanat. 2010. Parking infrastructure: Energy, emissions, and automobile life-cycle environmental accounting. Environmental Research Letters 5(7): PAGES. doi:10.1088/1748-9326/5/3/034001.

Chatman, D. 2009. Residential choice, the bult environment and nonwork travel: Evidence using new data and methods. Environment and Planning A 41: 1072-1089.

Chatman, D. 2010. Deconstructing development density: Quality, quantity and price effects on household travel. Transportation Research A, 2008 42(7): 1009-1031.

Chatman, D. 2013. Does TOD need the T? Journal of the American Planning Association 79(1): 17-31.

Chatman, D. 2014. Explaining the immigrant effect on auto use. Transportation 41: 441-4661.

Chu, Yu-Lian. 2002. Automobile ownership analysis using ordered probit models. Transportation Research Record. 1805: 60-67.

Davis, A., B. Pijanowski, K. Robinson, and B. Engel. 2010. The environmental and economic costs of sprawling parking lots in the United States. Land Use Policy 27(2): 255-261.

Fischel, W. 2002. The Homevoter Hypothesis. Cambridge, MA: Harvard University Press.

Giuiliano, G. 2003. Travel, location and race/ethnicity. Transportation Research 37(4): 351-372.

Curry, J. 2004. The Invisible Safety Net. Princeton, NJ: Princeton University Press.

Glaeser, E., and E. Luttmer. 2003. The misallocation of housing under rent control. American Economic Review 93(4): 1027-1046.

Guo, Z. 2013. Does residential parking supply affect household car ownership? A case of New York City. Journal of Transport Geography 26: 18-28.

Guo, Z. 2013 Residential street parking and vehicle ownership. Journal of the American Planning Association $79(1): 32-48$.

Handy, S. 2005. Smart growth and the transportation-land use connection: What does the research tell us? International Regional Science Review 28(2): 1-22.

Jacob, B. 2004. Public housing, housing vouchers, and student achievement. American Economic Review 94(1): 233-258.

Jakle, J., and K. Sculle. 2004. Lots of Parking: Land Use in a Car Culture. Charlottesville: University of Virginia Press.

Manville, M. 2013. Parking requirements and housing development: Regulation and reform in Los Angeles. Journal of the American Planning Association 79(1): 49-63.

Manville, M., A. Beata, and D. Shoup. 2013. Turning housing into driving: Parking requirements and 
density in Los Angeles and New York. Housing Policy Debate 23(2): 350-375.

Manville, M., and D. Shoup. 2005. People, parking and cities. Journal of Urban Planning and Development 131(4): 233-253.

McCahill, C., and N. Garrick. 2010. Influence of parking policy on built environment and travel behavior in two New England cities, 1960-2007. Transportation Research Record 2187: 123-130.

Murray, M. 2006. Avoiding invalid instruments and coping with weak instruments. Journal of Economic Perspectives 20(4): 111-132.

Papke, L. E., and J. M. Wooldridge. 1996. Econometric methods for fractional response variables with an application to 401(k) plan participation rates. Journal of Applied Econometrics 11: 619-632.

Ross, C. 2013. City wants a cutback on new parking. Boston Globe. July 5.

Salon, D. 2009. Neighborhoods, cars, and commuting in New York City. Transportation Research Part A 43: 180-196.

Schachter, J., R. Franklin, and M. Perry. 2003. Migration and geographic mobility in metropolitan and nonmetropolitan America, 1995-2000. Washington, DC: US Census Bureau.

Shoup, D. C. 2005. The high cost of free parking. Chicago: Planners Press, American Planning Association.

Taylor, P., R. Morin, D. Cohn, and W. Wang. 2008. Who moves? Who stays put? Washington, DC: Pew Research Center.

Texas Transportation Institute. 2011. Urban mobility study. http://mobility.tamu.edu/ums/.

US Census Bureau. 2002. New York City Housing and Vacancy Survey. http://www.census.gov/housing/ nychvs/data/2002/nychvs02.html.

van Wee, B. 2009. Self-selection: A key to a better understanding of location choices, travel behavior and transport externalities? Transport Reviews 29(3): 279-292.

Watson, G. 2007. Weighting and the American Housing Survey. Cityscape 9(2): 193-200.

Weinberger, R., M. Seaman, and C. Johnson. 2009. Residential off-street parking impacts on car ownership, vehicle miles traveled, and related carbon emissions: New York City case study. Transportation Research Record 2118: 24-30.

Weinberger, R. 2012. Death by a thousand curb cuts. Transport Policy 20: 93-102.

Zegras, C. 2010. The built environment and vehicle ownership and use: Evidence from Santiago de Chile. Urban Studies 47(8): 1793-1817. 


\section{Appendix: First stage regression results}

The IV estimates account for the potential endogeneity between bundled parking and vehicle ownership. The two instruments are the share of housing units in an MSA that have bundled parking and the share of housing units built before 1920. As discussed in the text, these two variables are highly collinear, and the only advantage to including both is to permit post-estimation tests of instrument validity. The first-stage regression results show that when both are included in the first-stage model, only the parking instrument is large and statistically significant. However, if the regression is run with only one instrument (regardless of which one), that instrument is large and statistically significant. As discussed in the text, using only one instrument does not change the second-stage results substantially.

Table A-1: First Stage Regression Results

\begin{tabular}{|c|c|c|}
\hline & \multicolumn{2}{|c|}{ Unit has Bundled Parking } \\
\hline & Model 1 & Model 2 \\
\hline Household Income $(\$ 1,000 \mathrm{~s})$ & $\begin{array}{l}0.0003369^{* * * *} \\
(0.0000698)\end{array}$ & $\begin{array}{l}.0003095^{* * * *} \\
(.0000815)\end{array}$ \\
\hline Central City & $\begin{array}{l}-0.0727151 * * * \\
(0.0085748)\end{array}$ & $\begin{array}{l}-.0703665^{* * *} \\
(.0086189)\end{array}$ \\
\hline Proportion $\mathrm{HH}$ w/BA or Higher & $\begin{array}{l}-0.0119017 \\
(0.0109514)\end{array}$ & $\begin{array}{l}-.0086466 \\
(.0128877)\end{array}$ \\
\hline Proportion HH Male & $\begin{array}{l}0.0204677 \\
(0.0172311)\end{array}$ & $\begin{array}{l}-.02555655 \\
(.0138412)\end{array}$ \\
\hline Proportion HH Children & $\begin{array}{l}0.0150427 \\
(0.0113932)\end{array}$ & $\begin{array}{l}.004441 \\
(.0203186)\end{array}$ \\
\hline Proportion HH Foreign Born & $\begin{array}{l}-0.0044489 \\
(0.0109215)\end{array}$ & $\begin{array}{l}.0259945^{*} \\
(.010718)\end{array}$ \\
\hline Proportion HH Black & $\begin{array}{l}0.0242822 \\
(0.0131675)\end{array}$ & $\begin{array}{l}.0042374 \\
(.0127991)\end{array}$ \\
\hline Proportion HH Age 65 or More & $\begin{array}{l}0.0025862 * * * \\
(0.0001945)\end{array}$ & $\begin{array}{l}.0419932 * * \\
(.0185519)\end{array}$ \\
\hline Year Structure Built & $\begin{array}{l}0.0363061 * * * \\
(0.0086074)\end{array}$ & $\begin{array}{l}.0024947 * * * \\
(.0002497)\end{array}$ \\
\hline Public Transit Available & $\begin{array}{l}-0.0174172 \\
(0.0131272)\end{array}$ & $\begin{array}{l}.0001048 \\
(.0107338)\end{array}$ \\
\hline Unit Within 1/2 Block of: & & \\
\hline Parking Lots & $\begin{array}{l}0.0175826 \\
(0.0094358)\end{array}$ & $\begin{array}{l}.017211 \\
(.0096091)\end{array}$ \\
\hline High-Rise Apartment Buildings & $\begin{array}{l}-0.0153615 \\
(0.0158531)\end{array}$ & $\begin{array}{l}-.0316299 \\
(.0243429)\end{array}$ \\
\hline Apartments $<4$ Stories & $\begin{array}{l}-0.0051336 \\
(0.013719)\end{array}$ & $\begin{array}{l}.0001935 \\
(.0181897)\end{array}$ \\
\hline Town Houses and Row Houses & $\begin{array}{l}-0.0355965^{* * *} \\
(0.008853)\end{array}$ & $\begin{array}{l}-.0339256^{* * *} \\
(.009623)\end{array}$ \\
\hline Single Family Homes & $\begin{array}{l}0.0610693 * * * \\
(0.0090461)\end{array}$ & $\begin{array}{l}.0458768^{* * * *} \\
(.0108822)\end{array}$ \\
\hline
\end{tabular}


Table A-1: First Stage Regression Results (continued)

\begin{tabular}{|c|c|c|}
\hline & \multicolumn{2}{|c|}{ Unit has Bundled Parking } \\
\hline & Model 1 & Model 2 \\
\hline Parks & $\begin{array}{l}0.0175826 \\
(0.0094358)\end{array}$ & $\begin{array}{l}.0047298 \\
(.0102007)\end{array}$ \\
\hline Apartments 4-6 Stories & $\begin{array}{l}-0.0632542 * * * \\
(0.011282)\end{array}$ & $\begin{array}{l}-.0439366^{* * *} \\
(.015747)\end{array}$ \\
\hline Industrial Buildings & $\begin{array}{l}-0.0165487 \\
(0.0166587)\end{array}$ & $\begin{array}{l}-.0372146 \\
(.0217512)\end{array}$ \\
\hline Abandoned Buildings & $\begin{array}{l}-0.1099102^{* * *} \\
(0.015544)\end{array}$ & $\begin{array}{l}-.082464 * * * \\
(.0241417)\end{array}$ \\
\hline Shops and Businesses & $\begin{array}{l}-0.0308997 * * * \\
(0.0085297)\end{array}$ & $\begin{array}{l}-.0261289^{* * * *} \\
(.0090338)\end{array}$ \\
\hline Share MSA Housing with Bundled Parking & $\begin{array}{l}0.9825385^{* * * *} \\
(0.1005087)\end{array}$ & $\begin{array}{l}.9209963 * * * \\
(.1473555)\end{array}$ \\
\hline Share MSA Housing Built before 1920 & $\begin{array}{l}0.0669483 \\
(0.1140085)\end{array}$ & $\begin{array}{l}.140303 \\
(.1584456)\end{array}$ \\
\hline Constant & $\begin{array}{l}-5.057708 * * * \\
(0.3910485)\end{array}$ & $\begin{array}{l}-4.817274^{* * *} \\
(.508781)\end{array}$ \\
\hline $\mathrm{N}$ & 4,958 & 3,337 \\
\hline $\mathrm{R}-\mathrm{Sq}$ & 0.19 & 0.16 \\
\hline
\end{tabular}

